\title{
Ortaokul Türkçe Ders Kitaplarındaki Metinlerin Değer Aktarımı Açısından İncelenmesi*
}

\section{Analysis of Secondary School Turkish Textbooks in Terms of Value Transmission*}

Yasemin BAKİ, Sorumlu Yazar. Dr. Öğr. Üyesi.

Recep Tayyip Erdoğan Üniversitesi, Eğitim Fakültesi, Türkçe ve Sosyal Bilimler Eğitimi Bölümü.

E-mail: ysmnbaki@gmail.com

ORCID: 0000-0003-4064-3724

ISSN: 1303-880X

e-ISSN: 2667-7504

http://ded.dem.org.tr

Geliş/Received: 14.09 .2018

Kabul/Accepted: 02.04 .2019

Makale türü/Article type

Araştırma/Research
Atıf/Citation: Baki, Y. (2019). Ortaokul Türkçe ders kitaplarındaki metinlerin değer aktarımı açısından incelenmesi. Değerler Eğitimi Dergisi, 17 (37), 109-146.

DOI: $10.34234 /$ ded.460042

* Bu çalışma, 12-14 Nisan 2018 tarihinde İstanbul'da düzenlenen Ders KitaplarıUluslararası Sempozyumunda (DEKUS 2018) sözlü olarak sunulan bildirinin içeriği geliştirilerek ve kısmen değiştirilerek hazırlanmıştır.

* This article is prepared through the paper presented on 12-14 April at the International Textbooks Symposium (DEKUS 2018) in Istanbul. 
Öz: Türkçe dersi ortaokul kitaplarında yaşayan ve evrensel değer aktarımının incelenmesinin amaçlandığı bu araştırmada nitel araştırma yöntemlerinden doküman incelemesi kullanılmıştır. Araştırmanın çalışma grubunun belirlenmesinde amaçlı örnekleme yöntemlerinden kolay ulaşılabilir durum örneklemesi kullanılmıştır. Bu yöntemle 2017-2018 eğitim öğretim yılında kullanılan 5, 6, 7 ve 8. sınıf Türkçe ders kitaplarında yer alan okuma metinleri ve şiirlerin tümü incelenmiştir. Araştırma kapsamında incelenen metinlerdeki değerlerin tespit edilmesinde UNESCO Değer Listesi, Yaşayan Değerler Listesi ve Rokeach'ın Değer Sınıflandırması kullanılmıştır. Veriler betimsel analiz yoluyla incelenmiştir. Araştırma sonucunda ortaokul Türkçe ders kitaplarında en çok kullanılan değerlerin; estetik, sevgi, nezaket, çalışkanlık; en az kullanılan değerlerin ise barış, sadelik, alçakgönüllülük, hoşgörü olduğu tespit edilmiştir. Ayrıca incelenen Türkçe ders kitaplarında değer aktarımının niceliksel olarak yoğun bir şekilde yapıldığg ancak sınıf düzeyleri açısından ders kitaplarındaki temalar ve değerlerin tam olarak örtüşmediği, bazı değerlere hiç yer verilmediği ve değerlerin gerek sınıf gerekse temalara dağılımında bir sistematik yapılanmanın olmadığı tespit edilmiştir.

Anahtar kelimeler: Yaşayan Değerler Listesi, UNESCO Değer Listesi, Rokeach'ın değer sınıflandırması, Ortaokul Türkçe ders kitapları, Değer.

$\&$

Abstract: This study, which is aimed at analysing the living universal 1 values transfer in secondary school Turkish textbooks, was formed by qualitative research methodology and designed by document review. A purposeful sampling method was used to determine the study group of the research. With this method, reading texts and poems in the 5th, 6th, 7th and 8th grade Turkish textbooks published in the academic year of 2017-2018 were analysed. For determining the values in the texts, Value Review Form prepared by Cengiz and Duran (2017) using UNESCO Value List, Living Values List and Rokeach's Value Classification was used. The data were analysed through descriptive analysis. As a result of the research, the most used values in secondary school Turkish textbooks were determined as; aesthetics, love, kindness and diligence; and the least used values were determined as; peace, simplicity, modesty and tolerance. Additionally, it has been found that the value transfer was carried out quantitatively and intensively in the analysed Turkish textbooks, but that the themes and values in the textbooks were not completely consistent with the grade levels of the textbooks, that some values were not addressed at all and there was no systematic structure in the distribution of values across the grades or the themes. 
Keywords: Living Values List, UNESCO Value List, Rokeach's Value Classification, Junior high school Turkish textbooks, Value.

\section{Giriş}

Değer kavramı, insan davranışlarına rehberlik eden ilke, inanç, eylemlerin yargılandığı standartlar olarak tanımlanmaktadır (Güven, 2014). İlk defa Znaniecki tarafından sosyal bilimlere kazandırılan bu kavram, Latince "kıymetli olmak" veya "güçlü olmak" anlamlarına gelen "valere" kökünden türetilmiştir (Bilgin 1995). Değer, insan yaşamının amacını, davranış, ilke ve önceliklerini önce zihin dünyasında şekillendiren kavramlar olarak tanımlanır. Üstün ahlaklı bireylerin yetişmesine katkı sağlayan duyuşsal kavramlar olan değerler, bireylerin inanç, duygu ve tercihlerini etkileyerek davranışlarının şekillenmesinde önemli işlevler üstlenmektedir (Ulusoy ve Dilmaç, 2012; Güven, 2014). Soyut, genelleştirilmiş davranış prensipleri olarak da değerlendirilen değerler aynı zamanda kültürel bilgilerdir (Aydın, 2003). İnsanın mutluluğunda etkin rol oynayan değerler (Tarhan, 2011); taklit, model alma ya da dil (okuma) yoluyla öğrenilir (Şen, 2008).

Değerlerin kullanımında yaş, cinsiyet, sosyal konum, eğitim durumu, yaşanılan çevre ve aile önemli etkenler arasında yer almaktadır. Değerlerin kazanılmasında ise aile, yakın çevre ve eğitim kurumları önemli görevler üstlenmektedir. Çocuk kendi bilişsel ve duyuşsal kaynaklarını bağımsız olarak yönetinceye kadar, ailenin değerlerine bağlı olarak hayatını sürdürür. Eğitim hayatının başlamasıyla birlikte de aile vasıtasıyla aktarılan değerler okulda aktarılan yeni değerlerle birleşerek yeniden bir yapılanma süreci başlar. Eğitim bu süreçte bireyin aileden getirdiği özgünlüğünde korunmasını sağlayarak değerlerin aktarım sürecini en iyi şekilde yönetmelidir (Çınar, 2013).

Eğitim bireylerin yetiştirildiği ve gelecek kuşaklara değer aktarımının yapıldığı bir süreçtir (Ergün, 1994). Değerlerin öğretilmesi, içselleştirilmesi ve aktarılması için bilinçli bir girişim olan değerler eğitiminin temel gayesi bireyin kendini tanıması, anlaması ve gerçekleştirmesidir (Keskin, 2008; Kılınç ve Akyol, 2009). Kısaca ailede başlayan değer aktarım süreci, okullarda öğretim programları aracılığıyla sistemli ve planlı bir şekilde yürütülmektedir. Eğitim kurumlarında derslerin yol haritası niteliğinde olan öğretim programlarında değer eğitimine yer verilmesi değerlerin aktarımında önemli işlevler üstlenmektedir (Kardaş ve Cemal, 2017). Öğretim programlarında amaçlanan ilke ve kazanımların ana taşıyıcıları (Çiftçi, Çeçen ve Melanlıŏlu, 2007) ve öğretim 
programının içerik ve amacının somut bir göstergesi olan ders kitapları, teknolojik yeniliklere karşın hâlâ ders içerisinde en yaygın olarak kullanılan kaynak ve materyaldir (K1lıç ve Seven, 2003; Bulut ve Orhan, 2012). Ders kitapları aynı zamanda ana dili öğretiminde de dil bilinci ve sevgisini kazandırmasının yanı sıra metinler aracılığıyla da değer eğitimine katkı sağlamaktadır (Coşkun ve Taş, 2008; Demirel, 2010; Sever, 2003). Türkçe dersi, öğrencilere ana dili becerilerini kazandırmanın yanı sıra temel değerlerimizin kazandırılmasına da hizmet eden bir kültür ve beceri dersidir (Akyol, 2010). Türkçe dersinde değer eğitimi, metinler aracıllğıyla gerçekleştirilmektedir. Millî değerlerle donanmış olmakla birlikte paydaşı olan evrensel değerlere erişmiş bireylerin yetiştirilmesinde seçkin edebî metinlerin kullanımı eğitim için vazgeçilmez bir zorunluluktur (Öz, 2012; Yurt ve Arslan, 2014). Ayrıca bu metinler, kimliğimizin dokunduğu organik ve dinamik bir tezgâh olarak geçmişle geleceği şimdide yeniden inşa eden ve bireylerde değer inşasında önemli roller üstlenen araçlardır. Yani edebî metinler Türkçe dersinde bir eğitim materyali olarak kültürlenme arac1 olmalarının yanı sıra millî ve manevî değerlerin aktarımında da aracı işlevi üstlenmektedir (Kaygana, Yapıc1, Aytan, 2013; Kırmızı, 2014).

Türkçe ders kitaplarındaki metinler, öğrencinin hayatla bağlantısını daha anlamlı kılmasını, yaşamdan zevk almasını ve mutlu olmasını sağlayacak değerlerle örülü olmalıdır (Mert, 2013; Sidekli, 2014; Tillman, 2014). Bu metinler, Türk edebiyatının seçkin örneklerini içeren, millî, manevî ve evrensel değerleri yansıtan, estetik zevk ve dil bilinci kazandırmalarının yanı sıra, öğretim programlarında öğrencilere kazandırılması öngörülen değerlerin yer aldığı ve değer aktarımı amacına katkı sağlayacak nitelikte olmalıdır (Bulut ve Orhan, 2012; Kemiksiz, 2018; Padem ve Aktan, 2014).

Türkçe ders kitaplarının işlevleri ve sahip olduğu önemden hareketle bu ders kitaplarındaki metinlerin değer aktarımındaki niteliğine ilişkin alanyazındaki araştırmalarda artış olduğu söylenebilir (Akyol, 2010; Bayram ve Elban, 2017; Belet ve Deveci, 2008; Çapoğlu ve Okur, 2015; Çelikpazu ve Aktaş, 2011; Ç1rak, Şahin, Özberk ve Eriş, 2014; Çiftçi, Çeçen ve Melanlıoğlu, 2007; Doğan ve Gülüş̧en, 2011; Fırat ve Mocan, 2014; Şen, 2008; Karagöz, 2009; Kardaş ve Cemal, 2017; Kaşkaya ve Duran, 2017; Kaygana, Yapıcı, Aytan, 2013; Kırmızı, 2014; Külünkoğlu, 2010; Mert, 2013; Padem ve Aktan, 2014; Pilav ve Erdoğan, 2016; Pilav, Demir ve Demir, 2015; Somuncu, 2010; Tosunoğlu ve Arslan, 2012; Yaman, Taflan ve Çolak, 2009). Türkçe öğretimi alanında değer aktarımı üzerine yapılan bilimsel çalışmalar son yıllarda belirli bir artış göstermesine 
karşın bu çalışmaların değer eğitimine katkısında nicelik ve nitelik olarak yetersiz kalındığ 1 söylenebilir (Kardaş ve Cemal, 2017). Değer eğitimine belirgin bir süre ayrılmadığı, değer eğitiminin örtük şekilde ifade edildiği (Kırmızı, 2014), öğretim programları incelendiğinde birçok ders için değerlerin henüz belirlenmediği ya da değerlere doğrudan değinilmediği bu alandaki sorunlardan bazılarıdır (Kardaş ve Cemal, 2017). Ayrıca Türkçe ders kitaplarının değer aktarımında yetersiz kaldığı, metinlerin değer aktarımında çeşitliliği sağlayamadığ1 (Çelikpazu ve Aktaş, 2011; Doğan ve Gülüşen, 2011; Mert, 2013; Pilav ve Erdoğan, 2016;Şentürk ve Aktaş, 2015), değer aktarımında sınıf düzeyine göre gelişimsel bir ivmeyle hareket edilmediği (Çelikpazu ve Aktaş, 2011; Doğan ve Gülüşen, 2011; Kaşkaya ve Duran, 2017), metinlerdeki değerlerin temalarla ilişkilendirilmesinde sorunlar olduğu (Kaygana, Yapıcı ve Aytan, 2013; Önkaş, Çulha, Şiveroğlu, 2011; Padem ve Aktan, 2014) tespit edilmiştir. Türkçe ders kitaplarında değerlerin içselleştirilmesine yönelik etkinliklere yeterince yer verilmediği (Kaygana, Yapıcı ve Aytan, 2013) ve ders kitaplarındaki değer aktarımının yeterli olmadığ1 çeşitli araştırmalarla ortaya konulmuştur (Çelikpazu ve Aktaş, 2011; Demir, 2012; Doğan ve Gülüşen, 2011; Frrat ve Mocan, 2014; Karagöz, 2009; Parlakyıldız, 2009; Pilav ve Demir, 2015; Somuncu, 2008; Şen, 2008; Şentürk ve Aktaş, 2015). Alanyazındaki araştırmalar incelendiğinde UNESCO Değer Listesi, Yaşayan Değerler Listesi ve Rokeach'ın Değer Sınıflandırması'nda yer alan değerlerin incelendiği her hangi bir araştırmaya erişilmemiştir. Türkçe ders kitaplarındaki metinler aracılığıyla aktarılan mevcut değerlerin yaşayan evrensel değerlerle ne düzeyde uyumlu olduğunun incelenmesi açısından dikkate değerdir. Ayrıca bu araştırma, bir kültür ve beceri dersi olan Türkçe dersinin amaçlarının gerçekleşmesinde millî değerlerden evrensele uzanabilmesinde mevcut yerinin görülmesi açısından önemli katkılar sağlayacă̆ı düşünülmektedir.

Eğitim sürecinde soyut işlemler dönemi olarak tanımlanan ortaokul dönemi değer ve inanç sisteminin yapılandırıldığı evredir (Demircan, 2006). Özellikle değerlerin yapılandırıldığı kritik bir evre olan bu dönemde Türkçe ders kitaplarının mevcut niteliklerini incelenmesinin ders kitaplarının gelişimi açısından da önemli faydalar sağlayacağı düşünülmektedir. Bu çerçevede Türkçe dersi ortaokul 5., 6., 7. ve 8. sınıf kitaplarında yer verilen değerlerin tespit edilmesi, bu değerlerin tema ve sınıf düzeyine göre dağılımının incelenmesi amaçlanmıştır. $\mathrm{Bu}$ amaç çerçevesinde belirlenen alt amaçlar şunlardır:

1.Türkçe dersi 5. sınıf kitabındaki metinler aracılığıyla aktarılan değerler nelerdir? Bu değerlerin ders kitabındaki temalara göre dağılımı nasıldır? 
2. Türkçe dersi 6. sınıf kitabındaki metinler aracılığıyla aktarılan değerler nelerdir? Bu değerlerin ders kitabındaki temalara göre dağılımı nasıldır?

3. Türkçe dersi 7. sınıf kitabındaki metinler aracıllı̆ıyla aktarılan değerler nelerdir? Bu değerlerin ders kitabındaki temalara göre dağılımı nasıldır?

4. Türkçe dersi 8. sınıf kitabındaki metinler aracılığıyla aktarılan değerler nelerdir? Bu değerlerin ders kitabındaki temalara göre dağılımı nasıldır?

5. Türkçe dersi ortaokul kitaplarında aktarılan değerlerin sınıf düzeyine göre dağılımı nasıldır?

\section{Yöntem}

\section{Araştırmanın Modeli}

Türkçe dersi ortaokul kitaplarındaki değer aktarımının incelenmesinin amaçlandığı bu çalışma, nitel araştırma yöntemiyle gerçekleştirilmiştir. Bu yöntemde; sosyal fenomenler, insan davranışları ve bu davranışların sebepleri, doğal süreci içerisinde gerçekçi ve bütüncül bir bakış açısıyla ortaya konulmaktadır (Condrad ve Serlin, 2011). Bu yöntemle gerçekleştirilen araştırmada doküman incelemesi deseni kullanılmıştır. Doküman incelemede, araştırılması hedeflenen olgu ve olaylar hakkında bilgi içeren yazılı, görsel ve dijital malzemelerin toplanıp incelenmesidir (Sönmez ve Alacapınar, 2011, Yıldırım ve Şimşek, 2011). Bu süreç, belli bir amaca dönük olarak kaynakları bulma, okuma, not alma ve değerlendirme işlemlerini içerir ve genel tarama ile içerik çözümlemesi olarak iki ayrı amaçla kullanılabilir (Karasar, 2005).

\section{Araştırmanın Çalışma Evreni}

$\mathrm{Bu}$ araştırmanın, çalışma evrenini Millî Eğitim Bakanlığı (MEB) tarafından basılmış ve Talim Terbiye Kurulu'nca onaylanmış Türkçe ders kitapları oluşturmaktadır. Bu çalışma evreninin belirlenmesinde ise amaçlı örnekleme yöntemlerinden kolay ulaşılabilir durum örneklemesi kullanılmıştır. Bu yöntemle belirlenen araştırmanın örneklemi 2017-2018 eğitim-öğretim yılında kullanılan 5., 6., 7. ve 8. sınıf Türkçe ders kitaplarında yer alan okuma metinleri ve şiirlerin tümünden oluşmaktadır. Ayrıca ders kitaplarında yer alan dinleme, izleme metni, serbest okuma metinleri de araştırmanın örneklemine dâhil edilmiştir. Bu örneklem 5, 6 ve 8. sınıf kitapları MEB yayınlarına, 7. sınıf kitabı ise EZDE yayınlarına ait olmak üzere toplam ört tane ders kitabından oluşmaktadır. $\mathrm{Bu}$ 
kitapların seçilmesindeki amaç; Türkçe öğretmenleriyle yapılan görüşmeler sonrasında Milli Eğitim Bakanlığı (MEB) tarafından basılmış olup okullarda en yaygın olarak kullanılan Türkçe ders kitapları olmalarıdır. 5. sınıf kitabında 8 tane nazım, 32 tane nesir olmak üzere 40 metin; 6. sınıf kitabında 8 tanesi nazım, 28 tanesi nesir olmak üzere 36 metin; 7. sınıf kitabında 5 tane nazım, 25 tane nesir olmak üzere 30 metin; 8. sinıf kitabında 8 tane nazım, 22 tane nesir olmak üzere toplam 30 metin incelenmiştir.

\section{Veri Toplama Aracı}

Nitel araştırmalarda yazılı kaynaklar; kitaplar, dergiler, makaleler vb. çeşitli dokümanlardan oluşurken görsel malzemeler ise resimler, slaytlar, filmler vb. malzemeler ve bu iki kategorinin dijital ortamdaki malzemeleri de nitel araştırmalarda kullanılacak dokümanlar olarak tanımlanmaktadır (Sönmez ve Alacapınar, 2011). Eğitim alanında ise ders kitapları, program yönergeleri, okul içi ve dışı yazışmalar, öğrenci kayıtları, toplantı tutanakları, öğretmen ve öğrenci el kitapları, öğrenci ders ödevleri ve sınavları vb. araştırmada kullanılacak dokümanlar arasında yer almaktadır (Yıldırım ve Şimşek, 2011). Araştırmada ortaokul Türkçe ders kitaplarından elde edilen verilerin analizinde Cengiz ve Duran (2017) tarafindan hazırlanan Değer İnceleme Formu kullanılmıştır. Bu form Yaşayan Değerler Listesi, UNESCO Değer Listesi ve Rokeach Değer Envanteri'nden alınan toplam 20 değerden oluşmaktadır. Araştırmada kullanılan bu formdaki değerlerin dağlımı Tablo 1'de sunulmuştur.

Tablo 1: Araştırmada Kullanılan Değer İnceleme Formunda Yer Alan Değerlerin Dağılımı

\begin{tabular}{lll}
\hline $\begin{array}{l}\text { Yaşayan Değerler Listesinden } \\
\text { Alınan Değerler }\end{array}$ & $\begin{array}{l}\text { UNESCO Değerler Listesinden } \\
\text { Alınan Değerler }\end{array}$ & $\begin{array}{l}\text { Rokeach'ın Değer Sinıflamasın- } \\
\text { dan Alınan Değerler }\end{array}$ \\
\hline $\begin{array}{l}\text { Alçak Gönüllülük } \\
\text { Barış }\end{array}$ & \\
Dürüstlük & Aile Birliğine Önem Verme & \\
Hoşgörü & Çalışkanlık & \\
İşbirliği & Dayanışma & Arkadaşlık \\
Mutluluk & Estetik & Nezaket \\
Özgürlük & Misafirperverlik & \\
Saygi & Temizlik & \\
Sevgi & Vatanseverlik & \\
Sorumluluk & Yardımseverlik & \\
Samimiyet & & \\
Sadelik & & \\
\hline
\end{tabular}


Tablo 1'e göre bu araştırmada ele alınan değerler barış, saygı, sevgi, işbirliği, mutluluk, dürüstlük, alçak gönüllülük, sorumluluk, hoşgörü, özgürlük, estetik, dayanışma, aile birliğine önem verme, çalışkanlık, misafirperverlik, temizlik, yardımseverlik, vatanseverlik, nezaket, arkadaşlık, samimiyet ve sadelik olmak üzere 22 değerden oluşmaktadır. Cengiz ve Duran (2017) Yaşayan Değerler Listesi'nden samimiyet değerini, ilgili araştırmanın çalışma evreninin soyut düşünme özelliği göz önüne alarak forma dâhil etmemesine karşın bu araştırmada ortaokul kitaplarının incelenmesi sebebiyle samimiyet ve sadelik değeri de bu forma eklenmiştir.

\section{Verilerin Analizi}

Araştırmada elde edilen veriler, betimsel analiz yoluyla incelenmiştir. Bu analizde, elde edilen veriler derin bir işleme tabi tutularak betimsel bir yaklaşımla önceden belirlenen temalar altında sunulması şeklinde gerçekleşmektedir (Y11dırım ve Şimşek, 2013). Öncelikle betimsel analizin kapsamı oluşturulmuş ve verilerin analizindeki boyutlara göre hangi temalar altında sunulacağ miştir. Bu kapsamda 5., 6., 7. ve 8. sinıflar için formlar oluşturulmuş ve bu formlar her kitapta yer alan temalara ve metinlerin isimlerine göre sinıfland1rılmıştır. Ardından bu kitaplardaki okuma metinleri, dinleme/izleme metinleri, serbest okuma metinleri ve şiirlerden oluşan dokümanlar sırasıyla incelenerek Değer İnceleme Formuna işaretlenmiştir. Tüm ders kitapları bu şekilde incelendikten sonra Değer İnceleme Formlarından elde edilen veriler ders kitaplarında yer alan temalar altında oluşturulan plan dâhilinde analiz edilmiş, özetlenmiş sınıf düzeyine göre sınıflandırılmıştır. Bu sınıflandırmanın ardından elde edilen bulgulara ilişkin frekans değerleri sınıf düzeyine göre tablolaştırılmıştır. İncelenen ders kitaplarındaki temaların sınıf düzeyine göre dağılımı ise Tablo 2'de sunulmuştur.

\begin{tabular}{llll}
\hline \multicolumn{3}{l}{ Tablo 2: Türkçe Dersi Ortaokul Kitaplarındaki Temaların Sınıf Düzeyine Göre Dă̆llımı } \\
\hline 5. Sınıf Kitabı & 6. Sınıf Kitabı & 7. Sınıf Kitabı & 8. Sınıf Kitabı \\
\hline Çocuk Dünyası & Biz ve Değerlerimiz & Millî Kültür & Okuma Kültürü \\
Millî Mücadele ve Atatürk & Millî Mücadele ve Atatürk & Atatürk & Atatürk \\
Erdemler & Dünya ve Çevre & Okuma Kültürü & Millî Kültür \\
Bilim ve Teknoloji & Millî Kültürümüz & Duygular & Kişisel Gelişim \\
Millî Kültür & Vatandaşlık Bilinci & Doğa ve Evren & Toplum \\
Okuma Kültürü & Sanat ve Toplum & Zaman ve Mekân & Hayatı \\
Sağlık, Spor & Bilim ve Teknoloji & & Zaman ve Mekân \\
Doğa ve Evren & Sağlık, Spor ve Oyun & & \\
\hline
\end{tabular}


Tablo 2'ye göre 5. ve 6. sinıfta 8 tema, 7. ve 8. sinıfta ise 6 tema olmak üzere toplamda Türkçe ders kitaplarında toplamda 24 tema yer almaktadır.

\section{Bulgular}

Araştırmanın bu bölümünde Türkçe dersi 5., 6., 7. ve 8. sınıf kitabında yer alan değerlerin sınıf düzeyine göre dağılımına ilişkin bulgular, tablolar ve grafikler şeklinde aşağıda sunulmuştur. Ayrıca her sınıf düzeyindeki metinlere ilişkin değerlere dair doğrudan alıntılara yer verilmiştir.

Tablo 3: Türkçe Dersi 5. Sınıf Kitabında Yer Alan Değerler

\begin{tabular}{|c|c|c|c|c|c|c|c|c|c|}
\hline Değerler & 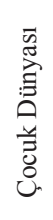 & 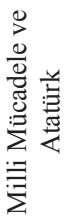 & 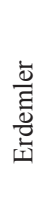 & $\begin{array}{l}:= \\
\frac{1}{0} \\
0 \\
0 \\
0 \\
0 \\
0 \\
0 \\
0 \\
0 \\
0\end{array}$ & 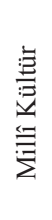 & 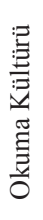 & $\begin{array}{l}\overline{0} \\
\text { की } \\
\text { है } \\
\bar{\Xi} \\
\tilde{\omega}\end{array}$ & 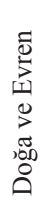 & $\frac{\Xi}{\text { ज्ञ }}$ \\
\hline & $\mathrm{f}$ & $\mathrm{f}$ & $\mathrm{f}$ & $\mathrm{f}$ & $\mathrm{f}$ & $\mathrm{f}$ & $\mathrm{f}$ & $\mathrm{f}$ & $\mathrm{f}$ \\
\hline Barış & - & 3 & 1 & - & - & - & 5 & - & 4 \\
\hline Sayg1 & 4 & 3 & 1 & - & 19 & 2 & 6 & - & 35 \\
\hline Sevgi & 19 & 21 & 14 & - & 4 & 10 & 18 & 18 & 104 \\
\hline İşbirliği & 4 & 4 & 4 & 14 & 3 & - & 24 & 5 & 58 \\
\hline Mutluluk & 16 & 5 & 8 & 3 & 17 & 8 & 9 & 46 & 112 \\
\hline Dürüstlük & 20 & 3 & 2 & 1 & 1 & 3 & 6 & 1 & 37 \\
\hline Alçak gönüllülük & 3 & - & - & 4 & 2 & 1 & - & - & 10 \\
\hline Sorumluluk & 17 & 4 & 1 & - & 1 & - & 43 & 10 & 76 \\
\hline Hoşgörü & 4 & - & 2 & - & 3 & - & 2 & 2 & 13 \\
\hline Özgürlük & 1 & 16 & 3 & - & 6 & - & 1 & 3 & 30 \\
\hline Estetik & 32 & 20 & 11 & 36 & 36 & 17 & 57 & 44 & 253 \\
\hline Dayanışma & - & 13 & 6 & 8 & 4 & - & 7 & 7 & 45 \\
\hline Aile Birliği & 4 & 23 & 8 & 2 & 4 & 2 & 9 & 5 & 57 \\
\hline Çalışkanlık & 2 & 2 & 4 & 18 & 3 & - & 1 & - & 44 \\
\hline Misafirperverlik & - & - & - & 1 & 2 & - & 4 & - & 7 \\
\hline Temizlik & - & - & - & 10 & 1 & 1 & 42 & 5 & 59 \\
\hline Yardımseverlik & 1 & 4 & 6 & 6 & 9 & - & 19 & 8 & 53 \\
\hline Vatanseverlik & 1 & 23 & - & 12 & 16 & - & 16 & - & 72 \\
\hline Nezaket & 11 & 2 & 41 & 6 & 27 & 5 & 19 & 15 & 126 \\
\hline Arkadaşlık & 6 & 4 & 7 & 5 & - & 4 & 5 & 7 & 38 \\
\hline Samimiyet & 16 & 14 & 5 & 5 & 10 & 1 & 8 & 40 & 99 \\
\hline Sadelik & 11 & 1 & 1 & 3 & - & - & - & 2 & 18 \\
\hline
\end{tabular}

Tablo 3'e göre Çocuk Dünyası temasında estetik ( $f=32)$, dürüstlük $(f=20)$ ve sevgi $(f=19)$; Millî Mücadele ve Atatürk temasında birlik $(f=23)$, vatanseverlik 
( $f=23)$; Erdemler temasında nezaket $(f=41)$ ve sevgi $(f=14)$; Bilim ve Teknoloji temasında estetik ( $f=36)$ ve çalışkanlık $(f=18)$; Millî Kültür temasında estetik $(f=36)$ ve nezaket $(f=27)$; Okuma Kültürü temasinda estetik $(f=17)$ ve sevgi $(f=10)$; Sağlik ve Spor temasında estetik $(f=57)$, sorumluluk $(f=43)$ ve temizlik $(f=42)$; Doğa ve Evren temasında ise mutluluk $(f=46)$, estetik $(f=44)$ ve samimiyet $(f=40)$ en fazla yer verilen değerlerdir.

Türkçe dersi 5. sınıf kitabında yer alan değerlere ilişkin doğrudan alıntılar:

Barış değerine yer veren ifade: "Aradan yüz yıl geçmeden barış içinde yaşadiğımız ülkemizde, 15 Temmuz 2016 gecesi hain bir saldırıya maruz kaldık."

Sayg1 değerine yer veren ifade: "15 Temmuz gecesi de darbecilere karşı ilk kurşunu sıkan Ömer Halis Demir gibi kahramanları tanıdı."

Sevgi değerine yer veren ifade: "Sen ne kadar da yorulmuşsun böyle." dedi. Ve sonra uyumast için güneşi kalbine yatırdl."

İşbirliği değerine yer veren ifade: "Burada üç astronot görev yapıyor. Astronotların görevi, burada çeşitli bilimsel deneyler gerçekleştirmenin yanı sıra istasyonun bakım ve onarımın yapmak."

Mutluluk değerine yer veren ifade: "Yani öyle bir güzel oynuyorum ki işte o kadar olur! Çocuklar gibi... Her şeyi unutuyorum. Dizlerimdeki o acımasız romatizma ăgrllarını bile... Her şeyi unutuyorum oyuncaklar arasında."

Dürüstlük değerine yer veren ifade: "Alis sık sık kendi kendine böyle güzel öğ̈̈tler verirdi. Ama onları tuttuğu pek söylenemezdi.". "Hatta bir keresinde kendi kendine oynadı̆̆ kroket oyununda hile yaptığı için kendisini tokatlamışt.."

Alçak gönüllülük değerine yer veren ifade: "Dost ve hasta ziyaretlerini unutmayınız, yaşlıları hatırlayınız. Onlara giderken bir deste hanımeli, bir iki sap iğde çiçeği, kır lalesi falan götürünüz."

Sorumluluk değerine yer veren ifade: Yağmur yüklü bulut: "İsterdim ama susuzluk çeken bir ülkeye yağmurlarımı boşaltmaya gidiyorum. Oradaki insanlar kaç haftadır beni bekliyorlar.

Hoşgörü değerine yer veren ifade: "Azıcık sabret Sareciğim, ben sana hepsini ögreteceğim."

Özgürlük değerine yer veren ifade: "19 Mayls 1919'da Mustafa Kemal ve arkadaşlarının Samsun'da başlattığı mücadele ile özgürlüğümüzü elde ettik."

Estetik değerine yer veren ifade: "Etiketin üzerinde güzel ve büyük harflerle "IÇ BENİ!” yazıllydl.". "Dayanışma değerine yer veren ifade: Bir zamanlar köy düğünlerini, davulu ile zurnası ile coşturan cirit oyunları Anadolu'nun kükrek sesi, yiğitlik, mertlik heyecanı, geleneksel seyirliğidir.” 
Aile birliği değerine yer veren ifade: "Derken efendim, pideleri aldım, eve geldim. Çoluk çocuk tüm aile sevinçle bana sarlldılar.". "Çünkü o, en basit ögütleri bile tutmadiklarl için elleri yüzleri yanan, vahşi hayvanlar tarafindan parçalanan ya da başına daha garip olaylar gelmiş çocuklara dair bir sürü hikâye biliyordu."

Çalışkanlık değerine yer veren ifade: "Sabah akşsam yavrularına yem taşıdı."

Misafirperverlik değerine yer veren ifade: "Komşuları hatır sormaya geliyorlar. İki gündür evde yaşayış değişmiş, herkesten slcak bir sevgi görüyor."

Temizlik değerine yer veren ifade: "Siralarımızın üstünü temiz tutmak bizim görevimizdir."

Yardımseverlik değerine yer veren ifade: "Bir de baktım ki köşse başında iki kişi kavga ediyorlar. Ayırayım diye aralarına girdim."

Vatanseverlik değerine yer veren ifade: “Yunus Emre'den, Mevlana'dan, Hacı Bektaş'tan, Hacı Bayram-ı Veli'den, Pir Sultan Abdal'dan, Koca Sinan'dan beslenen bu toprağın evlatları, zalimlere karşı istiklali ve istikbali için direndi. ,"

Nezaket değerine yer veren ifade: "Olur, oh, oh! Çok sevindim! Güle güle oturunuz, içinden hiç çıkmayınız!". "Her sanatın incelik gereken nazik kısmına da o günden sonra püf noktası denilmeye başlanır."

Arkadaşlık değerine yer veren ifade: "Sevgili dost okuma kitaplarım! Sizleri, zamanla bu kadar özleyeceğimi hiç bilmezdim."

Samimiyet değerine yer veren ifade: "Oyuncaklarla oynamak aslında çocukların hakkl. Ama ne yapabilirim? Bu yaşta olmama rağmen ben de seviyorum oyuncaklarla oynamayı!"

Sadelik değerine yer veren ifade: "Hatta yaşınız elveriyorsa şöyle gökkubbenin altında sırtüstü yatıverip taze ot kokusunu ciğerlerinize çekiniz."

Tablo 4: Türkçe Dersi 6. Sınıf Kitabında Yer Alan Değerler

\begin{tabular}{|c|c|c|c|c|c|c|c|c|c|}
\hline Değerler & 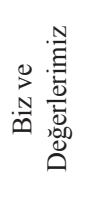 & 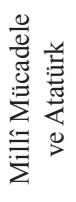 & 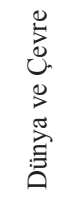 & 绿: & 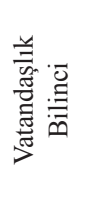 & 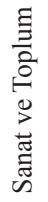 & 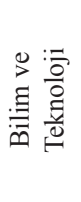 & 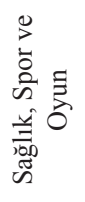 & 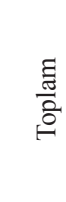 \\
\hline & $\mathrm{f}$ & $\mathrm{f}$ & f & $\mathrm{f}$ & $\mathrm{f}$ & $\mathrm{f}$ & $\mathrm{f}$ & $\mathrm{f}$ & $\mathrm{f}$ \\
\hline Barış & - & - & - & 4 & - & - & - & 5 & 9 \\
\hline Sayg1 & 10 & 24 & - & 9 & 11 & 2 & 1 & 2 & 59 \\
\hline Sevgi & 107 & 25 & 11 & 19 & 3 & 5 & 4 & 23 & 197 \\
\hline İşbirliğgi & - & 1 & 4 & 1 & - & 4 & 1 & 6 & 17 \\
\hline Mutluluk & 10 & 3 & 2 & 19 & 10 & 4 & 9 & 18 & 75 \\
\hline
\end{tabular}




\begin{tabular}{lccccccccc}
\hline Dürüstlük & 8 & - & - & 2 & 3 & 2 & - & 2 & 17 \\
\hline Alçak gönüllülük & 5 & - & - & - & 4 & 1 & - & - & 10 \\
\hline Sorumluluk & 4 & 13 & - & - & 15 & - & 2 & 14 & 48 \\
\hline Hoşgörü & 1 & - & - & - & - & - & 2 & 1 & 5 \\
\hline Özgürlük & 1 & 6 & - & 3 & - & - & - & 5 & 14 \\
\hline Estetik & 39 & 20 & 18 & 40 & & 9 & 1 & 9 & 136 \\
\hline Dayanışma & 1 & 12 & - & - & 9 & - & - & 12 & 34 \\
\hline Aile birliği & 3 & 7 & - & - & 5 & - & - & 3 & 18 \\
\hline Çalışkanlık & 6 & 12 & 4 & 2 & 69 & 1 & 32 & 3 & 129 \\
\hline Misafirperverlik & - & - & - & - & - & - & - & - & - \\
\hline Temizlik & - & - & - & - & - & - & 5 & - & 5 \\
\hline Yardımseverlik & 2 & - & 1 & - & 10 & - & 5 & 15 & 33 \\
\hline Vatanseverlik & - & 68 & - & 19 & 3 & 4 & - & 3 & 97 \\
\hline Nezaket & 15 & 31 & 11 & 2 & 11 & 54 & 1 & 8 & 133 \\
\hline Arkadaşlık & 2 & 4 & 4 & - & 2 & - & 1 & 8 & 21 \\
\hline Samimiyet & 5 & 2 & - & - & 6 & 2 & 1 & 7 & 23 \\
\hline Sadelik & - & - & - & - & - & - & - & - & - \\
\hline
\end{tabular}

Tablo 4'e göre Biz ve Değerlerimiz temasında en fazla sevgi $(f=107)$ ve estetik $(f=39)$; Millî Mücadele ve Atatürk temasında vatanseverlik $(f=68)$ ve nezaket $(f=31)$; Dünya ve Çevre temasında estetik $(f=18)$ ve sevgi $(f=11)$ değerine yer verildiği tespit edilmiştir. Millî Kültürümüz temasında estetik ( $f=40)$, vatanseverlik $(f=19)$, sevgi $(f=19)$ ve mutluluk $(f=19)$; Vatandaşlık Bilinci temasında çalışkanlık $(f=69)$ ve sorumluluk $(f=15)$; Sanat ve Toplum temasında nezaket $(f=54)$ ve estetik $(f=9)$; Bilim ve Teknoloji temasında çalışkanlık $(f=32)$ ve mutluluk $(f=9)$; Sağlik, Spor ve Oyun temasında sevgi $(f=23)$ ve mutluluk $(f=18)$ değerine yer verilmiştir. Bununla birlikte 6. sınıf düzeyinde sevgi $(f=197)$, estetik $(f=136)$, nezaket $(f=133)$ ve çalışkanlık $(f=129)$ en fazla kullanılan değerdir. Ayrıca 6. sınıf düzeyinde misafirperverlik ve sadelik değerine hiç yer verilmezken temizlik $(f=5)$, hoşgörü $(f=5)$ ve barış $(f=9)$ en az yer verilen değerler olarak tespit edilmiştir.

Türkçe dersi 6. sınıf kitabında yer alan değerlere ilişkin doğrudan alıntılar:

Mutluluk değerine yer veren ifade: “Anne ve babanın ses tonundaki yumuşaklık, ilgilerindeki sevecenlik, ilişkilerindeki özveri çocukta sevinç, neşe ve mutluluk duygularını doğurur.”. "Asıl mutluluğun dostlarının arasında görevlerini yaptı̆̆ında içinde hissettiği şey olduğunu anlamıştı."

Sayg1 değerine yer veren ifade: "Sizleri üzdüğüm için çok utanıyorum. Beni bağışlarsanız çok mutlu olacă̆ım.”

Sevgi değerine yer veren ifade: "Sevmenin ölçüsü, ölçüsüz sevmektir.” ."Tek cümleyle, sevgi olmadan "insan” olunamaz." 
İşbirliği değerine yer veren ifade: “Öküzler kağnılara koşuldu, yiyecek çıkınları hazırlandı. Cephaneler, gülleler, silahlar kağnılara yüklendi.,. "Kafile başkanı "Kimse geride kalmasın, birbirimizi kaybetmeyelim." diye bağırdı."

Dürüstlük değerine yer veren ifade: "Seni alçak seni, bir daha kanar mıyım ben senin sözlerine?"

Sorumluluk değerine yer veren ifade: "Yeni kuşağı, cumhuriyetin fedakâr öğretmen ve eğitimcileri, sizler yetiştireceksiniz. Eserin değeri, sizin ustalık ve özverinizin derecesiyle orantıl bulunacaktır."

Hoşgörü değerine yer veren ifade: "Öte yandan nereye götürüldüğünü anlayan yaşlı adam gizli gizli gözyaşı döküyor, oğlu ve torununa belli etmemeye çalışıyordu."

Özgürlük değerine yer veren ifade: "Onun içindir ki Türk milleti, bu paha biçilmez emanetini sonsuz istikballerin bir ufkundan öbür ufkuna sönmez bir güneş gibi taşılyacaktır."

Estetik değerine yer veren ifade: "Her desenin bir adı vardır: Yllanlı bahçe, horoz ibiği, güneş yangını, karınca izi, yürek ă̆rısı, cennet çiçeği, güvercin gözü bunlar arasındadır. Kimi uğur getirir, kimi mutluluk. Tümüyle iyilik ve güzellik..."

Dayanışma değerine yer veren ifade: "Türk kadını, erkeği cephede savaşırken evinde oturamazdl."

Aile birliği değerine yer veren ifade: "Babasina lazım olabilecek bütün malzemeleri hazırladıktan sonra, yatalak olan babasını yatağından kaldırdı ve kucakladiğl gibi arabaya attı."

Çalışkanlık değerine yer veren ifade: "Güldüm, başını okşadım: - Çalış! Daha çok çalış!'. "Üstün ödevinizin yerine getirilmesine yüksek çabalarla kendinizi adayacağınızdan hiç kuşkum yoktur."

Temizlik değerine yer veren ifade: "Illk olarak hastane bir güzel temizlendi, boya badana yapıldı. Yataklar, çarşaflar değisstirildi. Eli yüzü kir içindeki hastalar ylkanıp paklandl."

Yardımseverlik değerine yer veren ifade: "Barakanın bir köşesini temizledi hazırladı ve arabadan yüklendiği yată̆ oraya itina ile serdikten sonra diğer malzemeleri de taşıyarak babasını sırtlayıp yatağa yerleştirdi.",

Vatanseverlik değerine yer veren ifade: "Komutan Osman Bey ve diğer Türk askerleri, şehit olan bu bacılarının başardlğı büyük iş için gurur duydular." 
Nezaket değerine yer veren ifade: "Akdeniz'e sordum: Bana kendini tanitır mısın? Memnuniyetle efendim, dedi.". "Teşekkür edip ayrıldım. 'Su gibi aziz ol" dedi."

Arkadaşlık değerine yer veren ifade: “Aslan hastalanmış, bir mağaraya girip yatmış. Tilkiyi pek severmiş, onu da yanına çağırıp ahbaplık etmiş.". "Kişi ŭ̆runa çaba harcadığı nesneleri, kişileri sever; sevdikçe ilgisi artar."

Samimiyet değerine yer veren ifade: “-Allah'ım, biliyorum görevimi yapmadım. Çok yanlış davranışlarda bulundum. Beni önce sen affet, sonra da onların beni affetmesini sağla."

Tablo 5: Türkçe Dersi 7. Sınıf Kitabında Yer Alan Değerler

\begin{tabular}{|c|c|c|c|c|c|c|c|}
\hline Değerler & 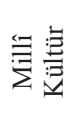 & 曾 & 范 & 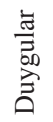 & 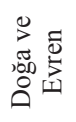 & 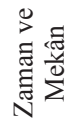 & $\frac{\Xi}{\frac{\Xi}{0}}$ \\
\hline & $\mathrm{f}$ & $\mathrm{f}$ & $\mathrm{f}$ & $\mathrm{f}$ & $\mathrm{f}$ & $\mathrm{f}$ & $\mathrm{f}$ \\
\hline Barış & - & 1 & 1 & - & 2 & - & 6 \\
\hline Sayg1 & 10 & 17 & 3 & 3 & 3 & 5 & 41 \\
\hline Sevgi & 31 & 6 & 23 & 14 & 21 & 1 & 96 \\
\hline İşbirliği & 4 & 7 & 9 & 5 & - & 3 & 28 \\
\hline Mutluluk & 14 & 4 & 33 & 38 & 17 & 9 & 115 \\
\hline Dürüstlük & 1 & - & 1 & 15 & - & - & 17 \\
\hline Alçak Gönüllülük & 4 & - & - & 6 & 1 & - & 11 \\
\hline Sorumluluk & 8 & 1 & - & - & - & 26 & 35 \\
\hline Hoşgörü & - & - & 3 & 7 & - & - & 10 \\
\hline Özgürlük & - & 4 & - & - & - & - & 4 \\
\hline Estetik & 85 & 21 & 72 & 49 & 198 & 28 & 453 \\
\hline Dayanışma & 4 & 2 & 13 & 14 & 5 & - & 38 \\
\hline Aile Birliği & 14 & 5 & 1 & 1 & - & - & 21 \\
\hline Çalışkanlık & 9 & 37 & 7 & 13 & 2 & 15 & 79 \\
\hline Misafirperverlik & 3 & - & - & - & - & - & 3 \\
\hline Temizlik & 6 & - & - & - & 5 & - & 11 \\
\hline Yardımseverlik & 9 & 1 & 14 & 18 & 14 & - & 56 \\
\hline Vatanseverlik & 22 & 100 & - & - & 3 & 8 & 133 \\
\hline Nezaket & 19 & 10 & 39 & 13 & 10 & 2 & 93 \\
\hline Arkadaşlık & 4 & - & 30 & 18 & 1 & - & 53 \\
\hline Samimiyet & 43 & 3 & 12 & 73 & 14 & 7 & 152 \\
\hline Sadelik & - & - & - & - & 1 & - & 1 \\
\hline
\end{tabular}

Tablo 5'e göre Millî Kültür temasında en fazla estetik ( $f=85)$ ve sevgi $(f=31)$; Atatürk temasında vatanseverlik $(f=100)$ ve çalışkanlık ( $f=37)$; Okuma Kül- 
türü temasında estetik $(f=72)$ ve nezaket $(f=39)$; Duygular temasında estetik $(f=49)$ ve mutluluk $(f=38)$; Doğa ve Evren temasında estetik $(f=198)$ ve sevgi $(f=21)$; Zaman ve Mekân temasında estetik $(f=26)$ ve sorumluluk $(f=28)$ değerine yer verilmiştir. Bununla birlikte 7. sınıf düzeyinde estetik ( $f=453)$, samimiyet $(f=152)$ ve vatanseverlik $(f=133)$ en fazla kullanılan değerlerdir. 7. sınıf düzeyinde sadelik $(f=1)$, misafirperverlik $(f=3)$, özgürlük $(f=4)$ ve barış $(f=6)$ ise en az yer verilen değerler olarak tespit edilmiştir.

Türkçe dersi 7. sınıf kitabında yer alan değerlere ilişkin doğrudan alıntılar:

Sevgi değerine yer veren ifade: "Ah gözünü sevdiğim küçük kilim! Ben senin alçakgönüllü olduğunu nasıl bilmem, bilirim.”

Barış değerine yer veren ifade: "Savaşta ve barışta kitapsız yola çıtktı̆̆ım olmaz".

Sayg1 değerine yer veren ifade: "Önce babamla annemin elini öptük, sonra birbirimizle kucaklaşıp öpüştük. '”

İşbirliği değerine yer veren ifade: "Az sonra amcamlar geldiler, babamı da alıp bayram namazına gittiler. Namazdan sonrada bahçede kurbanlar kesildi.,

Mutluluk değerine yer veren ifade: "Balıkçıl kuşu güzel haberler getiriyormuş. Götürdüğ̈̈ balıklar çok mutluymuş. Göldeki balıklar bu haberleri duyunca pek seviniyorlarmış."

Dürüstlük değerine yer veren ifade: "Ah bu türküler, köy türküleri. Mis gibi kokar, mis gibi toprak. Hilesi, hurdasız, çırllçıplak.”

Alçak gönüllülük değerine yer veren ifade: "Alçakgönüllüyüm, kalenderim ve haddimi bilirim."

Sorumluluk değerine yer veren ifade: "Annem günler öncesinden bayram hazırlığına başladı."

Özgürlük değerine yer veren ifade: "Bu şekilde hem kendini hem de göldeki diğer balıkların hayatını kurtarmış."

Estetik değerine yer veren ifade: "Dostluk ve samimilik berrak ve aydınlık kaldı̆̆ı müddetçe güzel bir şeydir. Üzerine bir gölge düştüğü zaman tüm güzelliği kaybolur"

Dayanışma değerine yer veren ifade: "Her vatandaş çevresine bu kadar renk ve düzen katmış olsaydı dünyamız çoktan cennete dönerdi.". "El birliği etmekle insan çok beladan kurtulur."

Aile birliği değerine yer veren ifade: "Allah bizi birbirimizden ayırmasın 
diye içimden dua ettim. Böyle ailemle birlikte olmak beni çok mutlu ediyor, ailemi dünyalara değişmem."

Çalışkanlık değerine yer veren ifade: "Bir ömür içine nasıl sı̆̆glıdı̆̆g kolayca anlaşılmayan bu eserler şunlardır: 81 cami, 400'den fazla mescid, 55 medrese, 26 darulkurra...."

Misafirperverlik değerine yer veren ifade: "Bu eğlenceler davet edilen bir köylü kadın da hediye olmak üzere bağındaki nefis üzümlerden bir sepet dolusu getirir."

Temizlik değerine yer veren ifade: "El öpmeye giderken pırll pırıl olmamızı ister annem."

Yardımseverlik değerine yer veren ifade: "Balıklar, balıkçıl kuşuna adeta yalvarmışlar. Bizden bu yardımı esirgeme diye ricada bulunmuşlar."

Vatanseverlik değerine yer veren ifade: "Millet sevgisini insan yalnız gazete sahifelerinde, meclis toplantılarında, onur mevkilerinde veya savaş meydanlarında değil, böyle mini mini isimde ve bir küçük köylü kızının yüzünde okuduğu zamandir..."

Nezaket değerine yer veren ifade: "Görgü kurallarını iyi öğrenelim. Büyüğe sayg1 duyup, küçükleri sevelim.". "Bana şeftali ikram edene baktım ..."

Arkadaşlık değerine yer veren ifade: "Dostluk kara günde belli olur. Ancak el ele verirsek dostumuz kurtulur.”. "Gönlünüzü açmadan evvel size uzanan ellerin, yakınlıkla açılan kolların hangi maksatla açıldığını araştırmayı bir zahmet saymayacaksinız."

Samimiyet değerine yer veren ifade: "Samimi olmak açılmak demektir. Samimi olmak, düşündüğümüzü saklamamak demektir.”

Sadelik değerine yer veren ifade: "Sadeliğiyle dikkat çeken, kemerli mermer türbesi Süleymaniye Camii dış avlusunun sol arka köşesindedir." 
Tablo 6: Türkçe Dersi 8. Sınıf Kitabında Yer Alan Değerler

\begin{tabular}{|c|c|c|c|c|c|c|c|}
\hline Değerler & 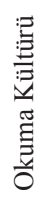 & 䲶 & 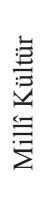 & 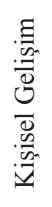 & 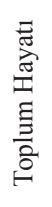 & 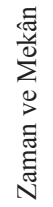 & $\frac{\Xi}{\frac{\Xi}{0}}$ \\
\hline & $\mathrm{f}$ & $\mathrm{f}$ & $\mathrm{f}$ & $\mathrm{f}$ & $\mathrm{f}$ & $\mathrm{f}$ & $\mathrm{f}$ \\
\hline Barış & - & 1 & - & - & - & - & 1 \\
\hline Sayg1 & 15 & 21 & 38 & 7 & 12 & 20 & 113 \\
\hline Sevgi & 39 & 17 & 85 & 23 & 29 & 12 & 205 \\
\hline İşbirliği & 1 & 2 & - & - & 11 & - & 14 \\
\hline Mutluluk & 17 & 16 & 19 & 11 & 23 & 13 & 99 \\
\hline Dürüstlük & 1 & 1 & 3 & 11 & - & - & 16 \\
\hline Alçak Gönüllülük & 4 & - & - & 2 & - & - & 6 \\
\hline Sorumluluk & 4 & 1 & - & 8 & - & 16 & 29 \\
\hline Hoşgörü & - & - & - & 13 & - & - & 13 \\
\hline Özgürlük & 1 & 3 & - & - & 4 & - & 8 \\
\hline Estetik & 39 & 26 & 51 & 21 & 26 & 68 & 231 \\
\hline Dayanışma & 8 & 53 & 2 & 5 & 34 & 2 & 104 \\
\hline Aile Birliği & 4 & 28 & 2 & - & 8 & 2 & 44 \\
\hline Çalışkanlık & 10 & 68 & 2 & 47 & 10 & 6 & 143 \\
\hline Misafirperverlik & - & 59 & - & - & 41 & - & 100 \\
\hline Temizlik & - & 5 & 2 & - & - & 1 & 8 \\
\hline Yardımseverlik & 4 & 60 & - & - & 15 & - & 79 \\
\hline Vatanseverlik & - & 20 & 45 & - & 11 & 9 & 85 \\
\hline Nezaket & 5 & 13 & 12 & 3 & 43 & - & 76 \\
\hline Arkadaşlık & 5 & - & - & - & 4 & - & 9 \\
\hline Samimiyet & 20 & - & 4 & 13 & 10 & - & 47 \\
\hline Sadelik & - & - & 4 & - & - & - & 4 \\
\hline
\end{tabular}

Tablo 6'ya göre Okuma Kültürü temasında sevgi $(f=39)$ ve estetik $(f=39)$; Atatürk temasında çalışkanlık ( $f=68)$ ve yardımseverlik $(f=60)$; Millı̂ Kültür temasında sevgi $(f=85)$ ve vatanseverlik $(f=45)$; Kişisel Gelişim temasında çalışkanlık ( $f=47)$ ve sevgi $(f=23)$; Toplum Hayatı temasında nezaket $(f=43)$, misafirperverlik ( $f=41$ ) ve dayanışma $(f=34)$; Zaman ve Mekân temasında estetik $(f=68)$ ve sayg $1(f=20)$ değerlerine yer verildiği tespit edilmiştir. Bununla birlikte 8. sınıf düzeyinde estetik $(f=231)$, sevgi $(f=205)$, çalışkanlık $(f=143)$ ve saygı ( $f=113$ ) en fazla kullanılan değerlerdir. Ayrıca 8 . sınıf düzeyinde barış $(f=1)$, sadelik $(f=4)$ ve alçak gönüllülük $(f=6)$ en az yer verilen değerler olarak tespit edilmiştir. 
Türkçe dersi 8. sınıf kitabında yer alan değerlere ilişkin doğrudan alıntılar:

Vatanseverlik değerine yer veren ifade: "Sonradan içime, kitaplardan geldiğini farkettiğim bir memleket hayâli, bana yıllarca arkadaşlık etti. Kendimi uzak bir diyarda hisse diyordum. Bir gün asıl vatanıma dönecektim.". "Millet sevgisi kadar büyük ödül yoktur."

Nezaket değerine yer veren ifade: "Gerçek manasında terbiyeli ve nazik bir adam veya bir hanım, tanıdığına, tanımadiğına, sevdiğine, sevmediğine iyi muamele etmeye, hatır saymaya, gönül almaya mecburdur.". "O zaman Atatürk davayı kaybeden arkadaşımıza dönerek bu sonucun yüksek klymetini küçültecek bir olay olmadı̆̆ın ifade ederek gönlünü aldı."

Alçak gönüllülük değerine yer veren ifade: "Ben yalnız kendi düşüncemi söylemek istemiyorum. Hepinizin düşüncelerini anlamak istiyorum."

Sorumluluk değerine yer veren ifade: "Milletimizi en geniş ve refah, vasita ve kaynaklarına sahip kılacağız."

Hoşgörü değerine yer veren ifade: "Empati kurmak ince bir sanattır “. "Gelin tanış olalım. İşi kolay kılalım.”

Sayg1 değerine yer veren ifade: "Hür ve mesut olarak hayat boyunca kendilerine saygl duyduğum hocalarım vardl."

Sevgi değerine yer veren ifade: "Sevgilerin ölümsüzlüğ̈̈ ile dolup taştı yüreğim."

İşbirliği değerine yer veren ifade: “Soğuk su Hellen'in bir eline akarken öğretmen diğer eline "su" sözcü̈g̈üü önce yavaş, sonra hızlıca heceledi. İste o anda Hellen 'in kalbi yerinden firlarcasına çarpmaya başladı."

Mutluluk değerine yer veren ifade: "Bu anda büyük Türk milletinin bir ferdi olarak bu kutlu güne kavuşmanın en derin sevinci ve heyecan içindeyim."

Dürüstlük değerine yer veren ifade: "Yalanla karşıllk vermezsen yalana"

Özgürlük değerine yer veren ifade: "Börteçine'yi kendi hakanları bildi; kimi de iyi görmedi, karşı çıktı. Onlarla da savaşıldı, Göktürkler hepsini yendiler.”

Estetik değerine yer veren ifade: "Türk milleti, Türk sanatı, Türk ekonomisi, Türk şiiri ile edebiyatı okul ve okulun vereceği bilim ve fen sayesinde bütün olağanüstü incelikleri ve güzellikleriyle oluşup gelişecektir."

Dayanışma değerine yer veren ifade: "Türk milleti çalışkandır. Türk milleti zekidir. Çünkü Türk milleti, milli birlik ve beraberlikle güçlükleri yenmesini bilmiştir." 
Çalışkanlık değerine yer veren ifade: "Yüksek bir insan cemiyeti olan Türk milletinin tarihi bir vasfi da güzel sanatları sevmek ve onda yükselmektir."

Misafirperverlik değerine yer veren ifade: "Misafirlik gündelik hayatımıza renkler katar."

Yardımseverlik değerine yer veren ifade: "Yunus, bu ortamda, bir aşk ve sevgi güneşi olarak Anadolu'da doğmuş, umutsuzlara umut vermiş, Anadolu'nun gönlü ve dili olmuştur."

Arkadaşlık değerine yer veren ifade: "Beni seven arkadaşlarıma öğüdüm şudur: Şahsımız için değil ancak bağhl bulunduğumuz millet için el birliğiyle çalışalım."

Samimiyet değerine yer veren ifade: "Millî emeller, millî irade yalnız bir şahsin düşünmesinden değil, millet fertlerinin tamamının arzularının, emellerinin birleşmesinden ibarettir. Bundan dolayı benden ne ögrrenmek, ne sormak istiyorsanız serbestçe sormanızı rica ederim."

Sadelik değerine yer veren ifade: "Tüm kötülüklerden arınmış, duru bir gönülle seslenir insanlığa:"

Tablo 7: Türkçe Dersi 5., 6., 7. ve 8. Kitabında Yer Alan Değerler

\begin{tabular}{lccccc}
\hline \multirow{2}{*}{ Değerler } & 5. sinıf & 6. sinıf & 7. sınıf & 8. sinıf & Toplam \\
\cline { 2 - 6 } & $f$ & $f$ & $f$ & $\mathrm{f}$ & $\mathrm{f}$ \\
\hline Barış & 4 & 9 & 6 & 1 & 20 \\
\hline Sayg1 & 35 & 59 & 41 & 113 & 248 \\
\hline Sevgi & 104 & 197 & 96 & 205 & 602 \\
\hline İşbirliği & 58 & 17 & 28 & 14 & 117 \\
\hline Mutluluk & 112 & 75 & 115 & 99 & 401 \\
\hline Dürüstlük & 37 & 17 & 17 & 16 & 87 \\
\hline Alçak Gönüllülük & 10 & 10 & 11 & 6 & 37 \\
\hline Sorumluluk & 76 & 48 & 35 & 29 & 188 \\
\hline Hoşgörü & 13 & 5 & 10 & 13 & 41 \\
\hline Özgürlük & 30 & 14 & 4 & 8 & 56 \\
\hline Estetik & 253 & 136 & 453 & 231 & 1073 \\
\hline Dayanışma & 45 & 34 & 38 & 104 & 221 \\
\hline Birlik & 57 & 18 & 21 & 44 & 140 \\
\hline Çalışkanlık & 44 & 129 & 79 & 143 & 395 \\
\hline Misafirperverlik & 7 & - & 3 & 100 & 110 \\
\hline Temizlik & 59 & 5 & 11 & 8 & 83 \\
\hline Yardımseverlik & 53 & 33 & 56 & 79 & 221 \\
\hline Vatanseverlik & 72 & 97 & 133 & 85 & 387 \\
\hline Nezaket & 126 & 133 & 93 & 76 & 428 \\
\hline & & & & &
\end{tabular}




\begin{tabular}{lccccc}
\hline Arkadaşlık & 38 & 21 & 53 & 9 & 121 \\
\hline Samimiyet & 99 & 23 & 152 & 47 & 321 \\
\hline Sadelik & 18 & - & 1 & 4 & 23 \\
\hline Toplam & 1350 & 1080 & 1456 & 1434 & 5320 \\
\hline
\end{tabular}

Tablo 7'ye göre 5. sinıf düzeyinde estetik ( $f=253)$, nezaket $(f=126)$, mutluluk $(f=112)$, sevgi $(f=104)$ en fazla; barış $(f=4)$, misafirperverlik $(f=7)$ ve hoşgörü $(f=13)$ ise en az yer verilen değerdir. 6. sınıf düzeyinde sevgi ( $f=197)$, estetik $(f=136)$, nezaket $(f=133)$ ve çalışkanlık $(f=129)$ en fazla yer verilen değerlerken misafirperverlik ve sadelik değerine hiç yer verilmediği; bununla birlikte en az temizlik $(f=5)$, hoşgörü $(f=5)$ ve barış $(f=9)$ değerlerine yer verildiği belirlenmiştir. 7. sınıf düzeyinde estetik $(f=453)$, samimiyet $(f=152)$ ve vatanseverlik $(f=133)$ en fazla; sadelik $(f=1)$, misafirperverlik $(f=3)$, özgürlük $(f=4)$ ve barış $(f=6)$ en az yer verilen değerdir. 8. sınıf düzeyinde estetik ( $f=231)$, sevgi $(f=205)$, çalışkanlık $(f=143)$ ve saygı $(f=113)$ en fazla; barış $(f=1)$, sadelik $(f=4)$, alçakgönüllülük $(f=6)$ en az yer verilen değerdir. 5., 6., 7. ve 8. sinıf düzeyindeki değerlere bütün olarak bakıldığında estetik ( $f=1073)$, sevgi $(f=602)$, nezaket $(f=428)$, çalışkanlık $(f=395)$, vatanseverlik $(f=387)$ ve mutluluk $(f=401)$ değeri en fazla; barış $(f=20)$, sadelik ( $f=23)$, alçakgönüllülük $(f=37)$, hoşgörü $(f=41)$ ve özgürlük $(f=56)$ değeri ise en az yer verilen değerlerdir. Sınıf düzeyine göre değerlerin aktarımı incelendiğinde; 5. sınıftan 6. sınıfa doğru bir düşüş olduğu, 7. sınıf düzeyinde en yüksek seviyeye ulaştığ 1 ve 7 . ve 8 . sınıf düzeyinde aktarılan değerlerin sıklığının ise birbirine yakın olduğu söylenebilir.

\section{Toplam Değer}

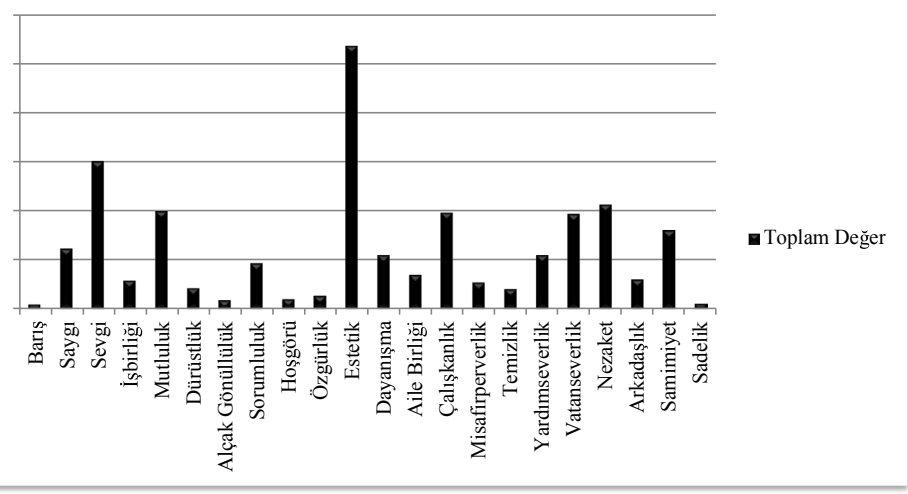

Şekil 1: Türkçe dersi 5, 6, 7. ve 8. sınıf kitabında yer alan değerlerin dağılımı 


\section{Sonuç ve Tartışma}

Bu araştırmada Türkçe dersi ortaokul kitaplarında yer alan değerler incelenmiştir. Araştırma sonucunda Türkçe dersi 5. sınıf kitabında estetik, nezaket, mutluluk ve sevgi en fazla yer verilen değer iken barış, misafirperverlik ve hoşgörü en az yer verilen değerlerdir. Benzer şekilde Padem ve Aktan (2014)'ın araştırma bulgularına göre okuma metinlerinde en fazla sevgi, yardımseverlik, estetik; en az ise acıma, arkadaşlık, cesaret, doğruluk, fedakârlık değerlerine yer verildiği tespit edilmiştir. Pilav ve Erdoğan (2016) tarafından yapılan araştırmada ise bilgilendirici metinlerde en çok sevgi ve ulusal değerlere yer verildiği, dürüstlük ve barış değerine ise hiç yer verilmediği belirlenmiştir. Ayrıca bu bulgu, Millî Kültür ve Okuma Kültürü temalarında dürüstlük ve barış değerine hiç yer verilmemesine ilişkin sonuçlarla da örtüşmektedir. Özelikle Okuma Kültürü ile Bilim ve Teknoloji temasındaki metinlerde değer aktarımında çeşitliliğin sağlanamadığı söylenebilir (Pilav ve Erdoğan, 2016). Ayrıca Erdemler temasında alçakgönüllülük değerine hiç yer verilmediği belirlenmiştir. Bu bulgulardan hareketle Türkçe dersi 5. sınıf kitabında tema ve değer uyumunun sağlanmasında sorunlar olduğu söylenebilir. Millî Mücadele ve Atatürk temasında da barış değerine çok az yer verilmiş olmasına ilişkin bulgu; Pilav ve Erdoğan (2016)'ın bulgularıyla örtüşmekle birlikte günümüzdeki savaşlara dikkat çekilmesi ve dünya barışına katkı sağlanması açısından yetersiz bir aktarım olarak değerlendirilebilir. Buna karşın 5. sınıf kitabında Millî Mücadele ve Atatürk temasında vatanseverlik ve aile birliği en fazla yer verilen değerler olup bu bulgunun ülkemizin içinden geçtiği bu zor dönemde kayda değer bir değer aktarımı olduğu söylenebilir. Ayrıca bu araştırmada Millî Mücadele ve Atatürk temasında vatanseverlik en fazla aktarımı yapılan değerken ders kitabı düzeyinde en fazla aktarımı yapılan değerin sevgi olduğu tespit edilmiştir. Bu bulgular Çırak, Şahin, Özberk ve Eriş (2014)'in bulgularıyla örtüşmektedir.

Araştırmada 6. sınıf ders kitabındaki yer alan metinlerdeki değerlerin dağılımı incelendiğinde; sevgi, estetik, nezaket ve çalışkanlık en fazla aktarılan değerdir. Bu ders kitabında misafirperverlik ve sadelik değerine hiç yer verilmezken temizlik, hoşgörü ve barış ise en az aktarılan değerdir. 6. sınıf ders kitabında en fazla sevgi değerine yer verilmiş olmasına ilişkin bulgu Şen (2008)'in araştırma bulgularıyla örtüşmezken; Pilav ve Erdoğan (2016)'in araştırma bulgularıyla örtüşmektedir. Benzer şekilde Şen (2008)'in araştırmasında incelediği ders kitaplarından dördünde; Çelikpazu ve Aktaş (2011)'ın araştırmasındaki 6. sınıf kitabında ise en fazla aktarılan değer sevgidir. Buna karşın Akyol (2010)'un araştırmasında Türk- 
çe dersi 6. sınıf kitaplarındaki Sevgi temasında değerlerin aktarımında, değer ve tutumlar açısından özel amaçlara inilmediği, temada duyuşsal alana oturtulması gereken kazanımların bilişsel hedeflerin çatısı altında kaldığı belirlenmiştir. Araştırmadan elde edilen bir diğer bulgu olan temizlik ve hoşgörü değerlerinin en az yer verilen değerler olması Aral (2008)'ın araştırma bulgularıyla benzerdir. Ayrıca bu araştırma sonucunda Biz ve Değerlerimiz, Millî Mücadele ve Atatürk, Dünya ve Çevre temasında barış değerine; Biz ve Değerlerimiz temasında misafirperverlik ve vatanseverlik değerine; Millî Kültürümüz temasında ise alçak gönüllülük, hoşgörü, misafirperverlik, yardımseverlik, aile birliği ve dayanışma değerlerine hiç yer verilmediği tespit edilmiştir. Bununla birlikte Biz ve Değerlerimiz ile Millî Kültürümüz teması içerik olarak da Türk kültürü ve değerlerini yansıtacak seçkin edebî metinlere yer verilmesine elverişli temalardır. Bu temalarda köklü bir geçmişe sahip milletimizin en başat özellikleri arasında yer alan hoşgörü, misafirperverlik, alçak gönüllülük ve yardımseverlik gibi değerlere yer verilmesinin Türkçe ders kitaplarında tema-değer uyumuna katkı sağlamasının yanı sıra değer aktarımı açısından da olumlu etkiler oluşturacağı söylenebilir. Benzer şekilde Vatandaşlık Bilinci temasında işbirliği; Sağlık, Spor ve Oyun temasında ise temizlik değerlerine hiç yer verilmediği tespit edilmiştir. Bu bulgulardan hareketle genel olarak Türkçe dersi 6. sınıf kitabında gerek tema düzeyinde gerekse kitabın bütününde bazı değerlere hiç yer verilmediği ve değerlerin aktarımında eksiklikler olduğu söylenebilir.

Araştırmada 7. sınıf düzeyinde değerlerin dağılımı incelendiğinde; estetik, samimiyet ve vatanseverliğin en fazla aktarılan; sadelik, misafirperverlik, özgürlük ve barışın ise en az aktarılan değerler olduğu tespit edilmiştir. Buna karşın Çelikpazu ve Aktaş (2011)'ın araştırması ile Pilav ve Erdoğan (2016)'ın araştırmasında sevgi değerinin, 7. sınıf düzeyinde en çok aktarılan değer olduğu belirlenmiş̧ir. Bu araştırmada misafirperverlik değerinin ders kitabının bütününde en fazla aktarılan değerler arasında olmasına ve tema açısından da Millî Kültür temasında hoşgörü, özgürlük ve barış değerine hiç yer verilmemiş olmasına ilişkin bulgular; Pilav ve Erdoğan (2016)'in bulgularıyla benzerdir. Ayrıca araştırmadan elde edilen bulgular temalar açısından değerlendirildiğinde; Atatürk temasında özgürlük ve barış değerine çok az yer verildiği tespit edilmiştir. Duygular temasında ise sorumluluk ve yardımseverlik değerlerine, Doğa ve Evren ile Zaman ve Mekân temasında ise birçok değere hiç yer verilmediği belirlenmiş̧ir. Türkçe dersi 7. sınıf kitabına ilişkin bulgular genel olarak değerlendirildiğinde; değer aktarımının istenilen düzeyde gerçekleşmediği ve mevcut temaları destekleyen değerlerin aktarımında da eksiklikler olduğu söylenebilir. 
Benzer şekilde Pilav, Demir ve Demir (2015)'in araştırmasında Türkçe dersi 7. sınıf kitaplarındaki okuma metinlerinde değer aktarımının amaçlanan düzeyde olmadığı tespit edilmiştir. Ayrıca Somuncu (2010)'nun, Türkçe ders 7. sınıf kitabındaki değerleri incelediği araştırma sonuçlarına göre; ders kitabındaki metinlerin üslup ve edebî açıdan daha sanatsal metinler olması gerektiği ve bu metinlerin öğrencilere değerleri öğreten şekilde değil içselleştirmelerini sağlayacak şekilde sunulması gerektiği belirlenmiştir.

Araştırmada 8. sınıf düzeyindeki değerlerin dağılımı incelendiğinde en fazla aktarılan değerlerin estetik, sevgi, çalışkanlık ve saygı; en az aktarılan değerlerin ise barış, sadelik, alçakgönüllülük olduğu tespit edilmiştir. Bu bulguların aksine Çelikpazu ve Aktaş (2011)'ın araştırmasında 8. sınıf düzeyinde estetik değerine yeterince yer verilmediği belirlenmiştir. $\mathrm{Bu}$ araştırma bulgularına göre sevgi ve çalışkanlık değerinin en çok kullanılan değerler arasında yer aldığı tespit edilmiştir. Benzer şekilde Çapoğlu ve Okur (2015)'un 8. sınıf düzeyindeki araştırmasında da insan sevgisi ve doğa sevgisi en çok aktarımı yapılan değerler arasında yer almaktadır. Çelikpazu ve Aktaş (2011)'ın araştırmasında ise 8. sınıf düzeyinde en fazla aktarılan değerin sevgi olduğu tespit edilmiştir. Bu araştırma sonucunda sevgi değerine ilişkin alan yazındaki araştırma bulgularının genel olarak birbirleriyle örtüştüğü söylenebilir. Bulgulara temalar açısından bakıldığında Toplum Hayatı temasında nezaket, misafirperverlik ve dayanışma en çok aktarılan değerlerdir. Toplumsal yaşama dair değerlere bizzat bu temada dikkat çekilmesi temalar ve temaları destekleyen değerlerin birbirleriyle uyumu açısından olumlu bir sonuç olarak değerlendirilebilir. Buna karşın Atatürk temasında, barış değerine çok az yer verildiği belirlenmiştir. Demir (2012)'in araştırmasında da 8. sınıf ders kitabında ulusal değerlerin istendik düzeyde okura sunulmadığ 1 belirlenmiştir. Araştırmadan elde edilen diğer bulgulara göre; Millî Kültür temasında alçakgönüllülük, hoşgörü ve özgürlük; Kişisel Gelişim temasında ise misafirperverlik, temizlik, yardımseverlik ve arkadaşlık değerlerine hiç yer verilmediği tespit edilmiştir. Toplum Hayatı temasında ise barış, dürüstlük, alçakgönüllülük, sorumluluk ve hoşgörü değerlerine hiç yer verilmemiş olması tema ve değer uyumu açısından ortaya çıkan belirgin sorunlar arasında sayılabilir. Bu bulgulardan hareketle tema düzeyinde değer aktarımıyla ilgili çeşitli sorunlar olmakla birlikte bu sorunların sadece belli temalarla sınırlı olduğu söylenebilir.

Araştırma kapsamındaki ders kitaplarına ilişkin bulgular bütün olarak incelendiğinde ders kitaplarında en fazla aktarılan değerler; estetik, sevgi, nezaket, 
çalışkanlık, vatanseverlik ve mutluluk iken en az aktarılan değerler ise barış, sadelik, alçakgönüllülük, hoşgörü ve özgürlüktür. Benzer şekilde Çırak, Şahin, Özberk ve Eriş (2014)'in araştırmasında incelediği kitapların tümünde en fazla aktarılan değer estetiktir. Çelikpazu ve Aktaş (2011)'ın bulgularına tüm ders kitapları açısından bakıldığında ise estetik değerine yeterince yer verilmediği belirlenmiştir. $\mathrm{Bu}$ araştırmada incelenen ders kitaplarına ilişkin bulgular bütün olarak incelendiğinde en fazla aktarılan değerin estetik olmasına ilişkin bulgu, ders kitaplarında seçilen edebî metinlerin estetik değerleri yansıttıkları bunun da ders kitaplarındaki metinlerin edebî güçleri açısından kaliteli olduğunun göstergesi olarak değerlendirilebilir. Çünkü edebî metin, kuru bilginin ötesine geçerek bilgiye estetik bir elbise giydirerek sunar ki bu da eserin edebî gücü olarak değerlendirilebilir (Somuncu, 2010).

Araştırma sonucunda elde edilen bir diğer bulgu da tüm ders kitaplarında estetikten sonra en çok aktarılan değerler; sevgi, nezaket, çalışkanlık, vatanseverlik ve mutluluktur. $\mathrm{Bu}$ araştırmada sevgi ve çalışkanlık değerine ilişkin bulgu; alanyazında Türkçe ders kitaplarındaki metinlerde değer aktarımının incelendiği pek çok araştırmayla örtüşmektedir (Belet ve Deveci, 2008; Çelikpazu ve Aktaş, 2011; Çırak, Şahin, Özberk ve Eriş, 2014; Fırat ve Mocan, 2014; Karagöz, 2009; Mert, 2013; Parlakyıldız, 2009; Şentürk ve Aktaş, 2015; Yılar, 2016; Yılmaz, Yakar, Arslan, Safranova ve Satbay, 2017). Ayrıca vatanseverlik değerine ilişkin bulgu da alanyazında ulusal değerlerin aktarımına ilişkin bulgularla benzerdir (Aral, 2008; Bayram ve Elban, 2017; Belet ve Deveci, 2008; Şen, 2008; Çelikpazu ve Aktaş, 2011; Doğan ve Gülüşen, 2011; Firat ve Mocan, 2014; Çırak, Şahin, Özberk ve Eriş, 2014). Buna karşın Türkçe ders kitaplarındaki değer aktarıma ilişkin çeşitli araştırmalarda millî değerlerin aktarımına çok az yer verildiği ya da hiç yer verilmediği tespit edilmiştir (Fırat ve Mocan, 2014; Pilav ve Erdoğan, 2016). Oysaki Türkçe Dersi Öğretim Programında ulusaldan evrensele uzanan bir anlayışla değerlerin aktarılması amaçlanmaktadır. Bu bağlamda ders kitaplarında yaşayan değerlere erişimin sağlanmasının ancak ulusaldan evrensele uzanan bir bakış açısına sahip bir eğitim anlayışıyla să̆lanacağl söylenebilir. Ayrıca araştırmada incelenen ders kitaplarında alçakgönüllülük, hoşgörü ve özgürlük değerlerinin en az yer verilen değerler olmasına ilişkin bulgu, kültürel değerlerimizin aktarımı açısından yeterli olmadığı söylenebilir. Türkçe ders kitaplarının hazırlanmasında ulusaldan evrensele uzanan bakış açısının sağlanması için öncelikle kadim Türk kültürünün aynası olan değerlerin sunulması hem kültürel değerlerimizin devamlılığı hem de evrensel değerlerin inşası adına olumlu katkılar sağlayacaktır. 
Araştırma sonuçları sınıf düzeyine ilişkin değer aktarımı açısından incelendiğinde ise 5. sınıf ders kitabındaki metinlerin değer aktarımı açısından 6. sınıftan daha zengin bir içeriğe sahip olduğu, bu zengin aktarımın 7. sınıf düzeyinde azalmakla birlikte 7. ve 8. sınıf düzeyinde metinlerin değer aktarımının birbirine yakın seviyede olduğu söylenebilir. Benzer şekilde Çelikpazu ve Aktaş (2011)'ın araştırmasında metinlerdeki değer aktarımının sınıf düzeyine göre artış göstermediği ayrıca bu araştırmanın bulgularının aksine 6. sınıfta değer aktarımının daha yoğun olduğu, 7. ve 8. sınıfta ise azaldığı tespit edilmiştir. Buna karşın Doğan ve Gülüşen (2011)'in araştırmasında ise değer aktarımının en fazla 8. sınıf ders kitabındaki metinlerde (58), sonra 6. sinıf ders kitabındaki metinlerde (56), en az da 7. sinıf ders kitabındaki metinlerde (51) yer aldığı belirlenmiştir. Ancak Yılar (2016)'ın araştırmasında Türkçe ders kitaplarındaki metinlerde aktarılan değerlerin sınıflara göre benzer şekilde dağılım gösterdiği tespit edilmiş̧ir. $\mathrm{Bu}$ sonuçlardan hareketle değer aktarımında öğretimdeki aşamalılık ilkesine göre hareket edilmediği söylenebilir.

Ayrıca araştırmada incelenen Türkçe ders kitaplarında değer aktarımının niceliksel olarak yoğun bir şekilde yapıldığı ancak sınıf düzeyleri açısından ders kitaplarındaki temalar ve değerlerin tam olarak örtüşmediği, bazı değerlere hiç yer verilmediği ya da çok az yer verildiği ve değerlerin gerek sınıf gerekse temalara dağılımında bir sistematik yapılanmanın olmadığı söylenebilir. Benzer şekilde Kaygana, Yapıcı ve Aytan (2013)'ın araştırmasında Türkçe ders kitaplarında metin seçimi ve seçilen metinlerin temalarla ilişkilendirilmesinde metin ile kazanımlar arasında tam uyuşma sağlanamadığı tespit edilmiştir. Açık Önkaş, Çulha, Şiveroğlu (2011) ise Türkçe ders kitaplarındaki şiir metinlerinin öğrencilerin kelime hazinesine katk1 sağlama, duygu ve değer eğitimi verme yönünden tema genişliğinin kısır kaldığını tespit etmiştir. Nitekim çeşitli araştırmalarda değerlerin temalarda orantılı bir şekilde dağılmadığı belirlenmiştir (Çelikpazu ve Aktaş, 2011; Padem ve Aktan, 2014;Pilav ve Erdoğan, 2016). Ayrıca alan yazında pek çok araştırmada da Türkçe ders kitaplarındaki değerlerin aktarımının yeterli düzeyde olmadığı ortaya konulmuştur (Çelikpazu ve Aktaş, 2011; Demir, 2012; Doğan ve Gülüşen, 2011; Frrat ve Mocan, 2014; Karagöz, 2009; Parlakyıldız, 2009; Pilav ve Demir, 2015; Somuncu, 2008; Şen, 2008). Şentürk ve Aktaş (2015),değerlerin ders kitaplarındaki (6-8. sınıf) metinlere dağılımında sorunlar olduğunu; Kaşkaya ve Duran (2017) ise değerlerin ders kitaplarına sınıf düzeylerine (1-4. sınıf) göre dağılımlarında tutarsızlıklar olduğunu tespit etmiştir. Doğan ve Gülüşen (2011)'in araştırmasında ise ders kitap- 
larında (6, 7 ve 8.sınıf) yer alan toplam 111 metnin 44'ünde; Pilav ve Erdoğan (2016)'in araştırmasında ortaokul Türkçe ders kitaplarındaki metinlerde bazı değerlere hiç yer verilmediği tespit edilmiştir. Mert (2013)'in araştırmasında da benzer sonuçlara ulaşılmıştır. Akyol (2010)'un araştırmasında ise Türkçe dersi 6. sınıf kitaplarında değer eğitiminde örtük program anlayışının benimsendiği tespit edilmiştir. Türkçe ders kitaplarında değerlerin aktarımındaki mevcut sorunlardan bir diğeri de metinlerdeki değerlerin davranış örnekleri üzerinden sunulmamasıdır. Ayrıca duyuşsal boyutu vurgulayan değerlerin içselleştirilmesi için sorgulanmasına, eyleme dökülmesine yönelik örnek ve etkinliklere yer verilmemektedir (Kaygana, Yapıcı ve Aytan, 2013). Bunun içinde metinlerde değerlerin aktarımında didaktik bir anlatım yerine dilin coşku ve heyecanını dile getirme işlevi kullanılmalı ve değer aktarımı metinlerdeki etkinliklerle de desteklenmelidir (Doğan ve Gülüşen, 2011; Kaygana, Yapıc1 ve Aytan, 2013).

Ortaokul evresinin değer ve inançların yapılandırıldığı soyut düşüncenin gelişim evresi (Demircan, 2006) olması sebebiyle bu evre; öğrencilerin millî, manevî, ahlâkî ve evrensel değerleri içeren metinlere yönelik algılarının geliştiği bir süreçtir (Fidan, 2018). Bu duruma Türkçe ders kitaplarındaki metinlerin değer aktarımında üstlendiği işlevde eklenince, ders kitaplarında kullanılacak metinlerin önemi daha da artmaktadır. Bu önemden hareketle değerlerin plan11 bir şekilde verilmesinin (Akyol, 2010) yanı sıra ders kitaplarına seçilecek metinlerle değer aktarımı desteklemeli ve kazandırılması amaçlanan değerler, öğretim programlarında net olarak ifade edilmelidir (Padem ve Aktan, 2014). Araştırma sonuçlarından hareketle Türkçe ders kitaplarında değer aktarımının yeterli düzeyde olmamasının yanı sıra bu kitapların ana kaynağı olan Türkçe Dersi Öğretim Programında (2017) değer eğitiminin sistemli bir şekilde ifade edilmediği söylenebilir. Çünkü mevcut programda değerlere ayrılan bölümde sadece millî, manevî ve evrensel değerleri tanıyan, benimseyen ve bunları içselleştirerek davranışa dönüştüren bireyler yetiştirilmesi gibi yüzeysel bir tanım yapılmıştır. Programda değer eğitiminde millî ya da evrensel değerlerin tam olarak hangi değerleri karşıladığı, bu aktarımda sınıf düzeyine göre dağılımın nasıl yapılacağı hakkında her hangi bir bilgi verilmemiştir. Sadece uygulama sürecinde her sınıf düzeyinde Erdemler, Millî Kültürümüz, Millî Mücadele ve Atatürk temalarının her sınıf düzeyinde işlenmesinin zorunlu olduğu ifade edilmiştir. Oysaki Türkçe Dersi Öğretim Programı (1-8. sınıf) farklı gelişimsel evrelerden oluşan sınıf düzeylerini kapsamaktadır. $\mathrm{Bu}$ durum sadece ortaokul seviyesi olarak düşünüldüğünde bile 5. sınıftan 8. sınıfa kadar gelişimsel birçok değişken devreye girmektedir. Türkçe ders kitaplarındaki değer aktarımındaki 
mevcut sorunların çözülmesinde öncelikle Türkçe Dersi Öğretim Programında değer eğitiminin nasıl yapılacağı, hangi değerlerin aktarımına öncelik verileceği, her sınıf düzeyi için ayrı ayrı düzenlenerek değer eğitimi sistematik bir yapıya kavuşturulmalıdır. Ayrıca seçilecek metinlerin temalarda vurgulanan değerlerle uyumuna ilişkin kriterlerin belirlenmesinin de değer eğitimi sürecine olumlu katkılar sağlayacağı söylenebilir. Ayrıca değer kavramının duyuşsal özelliklerinin yanı sıra toplumda ve dünyada meydana gelen değişimin oluşturduğu etkilere bireyin uyum sağlayabilmesi için o süreçte ön plana çıkan millî ve evrensel değerlere dikkat çekecek şekilde ders kitaplarında yer alacak metinlerin seçimi sağlanabilir. Türkçe Dersi Öğretim Programında ve beraberinde Türkçe ders kitaplarında değer aktarımının statik değil dinamik bir yapıda sürekli güncellenmesinin pozitif etkiler oluşturacağı da söylenebilir. Bu kapsamda Türkçe Dersi Öğretim Programında her sınıf düzeyine ilişkin sosyal, psikolojik, gelişimsel değişkenlerinde birlikte düşünüldüğü değerlere ilişkin çerçeve programları oluşturulabilir. Bununla birlikte değer aktarımında her sınıf düzeyinde kullanılacak metin türleri ve metinlerde kullanılacak etkinlikler, değer aktarımının sınıf düzeyi/tema/metin bağlamında dağılımına ilişkin kriterler, değer aktarımında başvurulacak kaynak ve yöntemler ayrı ayrı belirtilerek Türkçe öğretim sürecinde değer eğitimi daha sistematik bir yapıya kavuşturulabilir. Böylelikle değer eğitiminin, Türkçe öğretimi boyutunda bir ayağıyla millî değerlerde sabit diğer ayağıyla da her geçen gün evrensel değerlerde daha üst noktalara taşınmasına katk1 sağlanacağı söylenebilir.

\section{Kaynakça}

Açık-Önkaş N., Çulha B. ve Şiveroğlu E. (2011). Türkçe ders kitaplarındaki şiirlerin fonetik-semantik ilişkisine eleştirel bir yaklaşım. 2. Uluslararası Türk Dili ve Edebiyatı Sempozyumu (Dil ve üslûp incelemeleri), 19-21 Ekim 2011, Isparta.

Akyol, Ş. (2010). İlköğretim 6. Sınıf Türkçe ders kitaplarında yer alan sevgi temasının değerler eğitimi açısından incelenmesi. Yüksek lisans tezi. Çanakkale On sekiz Mart Üniversitesi, Çanakkale.

Aral, D. (2008). Millı̂ Eğitim Bakanlı̆̆ı'nın hazırladı̆̆ı 6. Sinıf Türkçe ders kitabında yer alan değerler üzerine bir araştırma. Yayımlanmamış yüksek lisans tezi, Abant İzzet Baysal Üniversitesi, Eğitim Bilimleri Enstitüsü, Bolu.

Aydın, M. (2003). Gençliğin değer algısı: Konya örneği. Değerler Eğitimi Dergisi, 1(3), 121-144. 
Bayram, B. ve Elban, M. (2017). Türkçe ders kitaplarında milli kimliğe ilişkin unsurların incelenmesi. Akdeniz Eğitim Araştırmaları Dergisi, 21, 19-27.

Belet, Ş. D. ve Deveci, H. (2-4 Mayıs 2008). Türkçe ders kitaplarının değerler bakımından incelenmesi. Çanakkale 18 Mart Üniversitesi: VII. Sınıf Öğretmenliği Sempozyumu.

Bulut, M. ve Orhan, S. (2012). Türkçe-edebiyat ders kitaplarının dil ve kültür aktarımındaki rolü ve önemi üzerine bir inceleme. Thejournal Of Academic Social Science Studies, 5(8), 297-311.

Bilgin, N. (1995). Sosyal psikolojide yöntem ve pratik çalışmalar. İstanbul: Sistem Yayıncilik.

Condrad, C. F. ve Serlin, R. C. (2011). Research Education. USA: SAGE Publications.

Coşkun, E. ve Taş, S. (2008). Ders kitaplarına metin seçimi açısından Türkçe öğretim programlarının değerlendirilmesi. Mustafa Kemal Üniversitesi Sosyal Bilimler Enstitüsü Dergisi, 5(10), 59-74.

Cengiz, Ş. ve Duran, E. (2017). Okul öncesi dönemine ait hikâye ve masallardaki değerlerin incelenmesi. Eğitim ve Bilim, 42(191), 205-233.

Çapoğlu, E. ve Okur, A. (2015). Ortaokul 8. sınıf Türkçe ders kitaplarındaki şiirlerde yer alan değerler. Sakarya University Journal Of Education, 5(3), 90-104.

Çelikpazu, E. E. ve Aktaş, E. (2011). MEB 6, 7 ve 8. Sınıf Türkçe ders kitaplarında yer alan metinlerin değer iletimi açısından incelenmesi. Turkish Studies, 6(2), 413-424.

Çınar, A. (2013). Değerler felsefesi ve psikolojisi. Bursa: Emin Yayınları.

Çırak, G., Şahin, D. B., Özberk, E. B. ve Eriş, H. M. (2014). The investigation of the texts in fifth grade Turkish course book in aspect of the values it conducts. Mediterranean Journal of Humanities, 4(1), 83-95.

Çiftçi, Ö., Çeçen, M. A. ve Melanlığlu, D. (2007). Altıncı sınıf Türkçe ders kitaplarındaki metinlerin okunabilirlik açısından değerlendirilmesi. Elektronik Sosyal Bilimler Dergisi, 6(22), 206-219.

Demir, T. (2012). İlköğretim sekizinci sınıf Türkçe ders kitaplarındaki hikâye metinlerinde yer alan değer unsurlarının eşdizimsel örüntülemeler açısından görünümleri. Turkish Studies, 7(2), 1063-1078.

Demirel, Ö. (2010). Öğretim ilke ve yöntemleri-öğretme sanatı. Ankara: Pegem Yayınlar1.

Demircan, C. (2006). Mektepli gazetesi’nde yer alan metinlerin içeriğinin çocukların bilişsel ve ahlaki gelişmelerine katkısı (1-148. Sayılar). Yayımlanmamış yüksek lisans tezi, Mersin Üniversitesi, Mersin. 
Doğan, B. ve Gülüşen, A. (2011). Türkçe ders kitaplarındaki (6-8) metinlerin değerler bakımından incelenmesi. Kilis 7 Aralı Üniversitesi Sosyal Bilimler Dergisi, 1(2), 75-102.

Ergün, M. (1994). Eğitim sosyolojisine giriş. (Eğitim ve Toplum). Ankara: Ocak Yayınları.

Fırat, H. ve Mocan, A. (2014). Türkçe ders kitaplarındaki hikâyelerde yer alan değerler. Türkiye Sosyal Araştırmalar Dergisi, 18(3), 25-49.

Fidan, M. (2018). Ortaokul öğrencilerinin Türkçe ders kitaplarında yer alan metinlere yönelik tutumlarının değerlendirilmesi. Erciyes Journal of Education [EJE], 2(1), 19-38.

Güven, A. Z. (2014). Değerler ĕgitimi ve Türkçe derslerinde değerlerin kullanımı. Konya: Palet Yayınları.

Karasar, N. (2005). Bilimsel araştırma yöntemi. Ankara: Nobel Yayıncılık.

Kardaş, M. N. ve Cemal, S. (2017). Değerler eğitimi ve Türkçe öğretiminde değer eğitimi üzerine yapılan araştırmalara ilişkin kaynakça denemesi. Karadeniz Sosyal Bilimler Dergisi, 9(16), 383-412.

Karagöz, B. (2009). Yapılandırmacı yaklaşıma göre ilköğretim 6 ve 7. Sınıf türkçe ders kitaplarındaki değerlerin incelenmesi (Muğla ili örneği). Yayımlanmamış yüksek lisans tezi, Muğla Üniversitesi, Muğla.

Kaşkaya, A. ve Duran, T. (2017). İlkokul Türkçe ders kitaplarının değer aktarımı açısından incelenmesi. Trakya Üniversitesi Eğitim Fakültesi Dergisi, 7(2), 417-441.

Kaygana, M., Yapıcı, Ş. ve Aytan, T. (2013). Türkçe ders kitaplarında değer eğitimi. International Journal of Social Science, 6(7), 657-669.

Kemiksiz, Ö. (2018). Yazar ve metin tercihleri bakımından Türkçe ders kitapları. Tarih Okulu Dergisi (TOD) 11(33), 945-967.

Keskin, Y. (2008). Türkiye'de sosyal bilgiler ögretim programlarında değerler ĕgitimi: Tarihsel gelişim, 1998 ve 2004 programlarının etkililiğinin araştırılması. Yayımlanmamış doktora tezi, Marmara Üniversitesi, İstanbul.

Kılıç, A. ve Seven, S. (2003). Konu alanı ders kitabı incelemesi. Ankara: Pegem Yayıncilık.

Kılınç A. ve Akyol Ş. (2009). İlköğretim 6. Sınıf Türkçe ders kitaplarında yer alan sevgi temasının değerler eğitimi açısından incelenmesi. The First International Congress Of Educational Research, 1-3 Mayıs Çanakkale.

Kırmızı, F. (2014). 4. Sınıf Türkçe ders kitabı metinlerinde yer alan değerler. Değerler Eğitimi Dergisi, 12(27), 217-259. 
Külünkoğlu, T. (2010). İlkögrretim birinci kademe Türkçe ders kitaplarındaki metinlerin ilettiği değerler açısından incelenmesi. Yayımlanmamış yüksek lisans tezi. Atatürk Üniversitesi, Erzurum.

MEB. (2017). İlköğretim Türkçe dersi öğretim programı ve kılavuzu (1-8. Sınıflar). Ankara: MEB Yayınları.

Mert, E. L. (2013). İlköğretim 6, 7 ve 8. Sınıf Türkçe ders kitaplarında yer alan öykü metinlerindeki değerlerin eşdizimli sözcükler bağlamında incelenmesi. Illkögretim Online, 12(3), 808-821.

Öz, G. (2012). Illköğretim sekizinci sınıf Türkçe ders kitaplarının söz varlı̆̆ bakımından incelenmesi. Yayımlanmamış yüksek lisans tezi, İnönü Üniversitesi, Malatya.

Padem, S. ve Aktan, O. (2014). İlköğretim 5. Sınıf Türkçe ders kitabında yer alan değerlerin incelenmesi. Düzce Üniversitesi Sosyal Bilimler Enstitüsü Dergisi, 4(2), 5-24.

Parlakyıldız, H. (2009). İlkokul ikinci devrede Türkçe ders kitaplarındaki moral değerlere kısa bir bakış (1948-1968 yılları aras1). Uludă̆ Üniversitesi Ĕgitim Fakültesi Dergisi, 22(1), 245-262.

Pilav, S., Demir, H. A. Ve Demir, H. (2015). İlköğretim 7. Sınıf Türkçe ders kitaplarındaki okuma metinlerinin değer iletimi açısından incelenmesi. Milli Ë̆itim Dergisi, 45(206), 16-29.

Pilav, S. ve Erdoğan, Ş. (2016). Ortaokul Türkçe ders kitaplarındaki bilgilendirici metinlerin değer iletimi açısından incelenmesi. Milli Eğitim Dergisi, 45(210), 351-371.

Sidekli, S. (2014). Metin öğretimi. M. Yılmaz (Ed.). Yeni gelişmeler işı̆̆ında Türkçe ögretimi (S. 167-199). Ankara: Pegem Yayınları.

Somuncu, S. (2010). İlköğretim Türkçe ders kitabındaki edebî metinlerin içerdiği evrensel değerlere ve metin seçimine ilişkin bazı tespitler. Selçuk Üniversitesi Edebiyat Fakültesi Dergisi (SEFAD), (24), 193-219.

Sönmez, V. ve Alacapınar, F. G. (2011). Örneklendirilmiş bilimsel araştırma yöntemleri. Ankara: Anı Yayıncılık.

Şen, Ü. (2008). Altıncı sınıf Türkçe ders kitaplarındaki metinlerin ilettiği değerler açısından incelenmesi. Uluslararası Sosyal Araştırmalar Dergisi, 1(5), 763.

Şentürk, L. ve Aktaş, E. (2015). Türkiye'de ve Romanya'da okutulan ana dili Türkçe ders kitaplarının değer iletimi açısından karşılaştırılması. Değerler Eğitimi Dergisi, 13(29), 215-243. 
Tarhan, N. (2011). Güzel insan modeli. İstanbul: Timaş Yayınları.

Tillman, D. (2014). 8-14 Yaş grubu ögrencileri için yaşayan değerler eğitimi etkinlikleri. (Çev. Ed. V. Aktepe). Konya: Eğitim Yayınevi.

Tosunoğlu M. ve Arslan F. (2012). İlköğretim 6.-8. Sınıf Türkçe ders kitaplarının çocuklara öğretilecek değerler açısından incelenmesi. 3. Ulusal Çocuk ve Gençlik Edebiyatı Sempozyumu: 5- 7 Ekim 2011. Ankara: Ankara Üniversitesi Basımevi.

Ulusoy, K. ve Dilmaç, B. (2012). Değerler eğitimi. Ankara: Pegema Yayıncılık.

Yaman, H., Taflan, S. ve Çolak, S. (2009). İlköğretim ikinci kademe Türkçe ders kitaplarında yer alan değerler. Değerler Eğitimi Dergisi, 7(18), 197-120.

Yılar, R. (2016). İlettiği değerler açısından ilkokul Türkçe ders kitaplarındaki metinler üzerinde incelemeler. Bayburt Eğitim Fakültesi Dergisi, 11(2), 490-506.

Yıldırım, A. ve Şimşek, H. (2011). Sosyal bilimlerde nitel araştırma yöntemleri. Ankara: Seçkin Yayıncılık.

Yılmaz, O., Yakar, Y. M., Arslan, M. A., Safranova, L. ve Satbay, G. (2017). Ortaokul ders kitaplarındaki kurgusal metinlerden hareketle değerler analizi: Türkiye ve Kazakistan örneği. Uluslararası Türkçe Edebiyat Kültür Eğitim (TEKE) Dergisi, 6(4), 2694-2710.

Yurt, G. ve Arslan, M. (2014). 7. Sınıf Türkçe ders kitaplarının şekil-içerik-metin yönünden incelenmesi: Zambak ve Pasifik Yayınları neği. Süleyman Demirel Üniversitesi Fen Edebiyat Fakültesi Sosyal Bilimler Dergisi, 31, 317-327.

\section{İncelenen Ders Kitapları}

MEB (2017). 5. sınıf Türkçe ders kitabı. Ankara: MEB Yayınları.

MEB (2017). 6. sınıf Türkçe ders kitabı. Ankara: MEB Yayınları.

EZDE (2017). 7. sınıf Türkçe ders kitabı. Ankara: EZDE Yayınları.

MEB (2017). 8. sınıf Türkçe ders kitabı. Ankara: MEB Yayınları. 


\title{
Analysis of Secondary School Turkish Textbooks in Terms of Value Transmission
}

\author{
Yasemin BAKI, Corresponding Author. Assistant Professor. \\ Recep Tayyip Erdoğan University, Faculty of Education, Department of Turkish and \\ Social Sciences Education.
}

E-mail: ysmnbaki@gmail.com

ORCID: 0000-0003-4064-3724

\section{Introduction}

The concept of value is defined as the standards in which principles, beliefs and actions that guide human behaviours are judged (Güven, 2014). This concept, which was first introduced to the social sciences by Znaniecki, was derived from the root of "valere" which means "to be precious" or "to be strong"in Latin (Bilgin 1995). Value is defined as concepts that shape the purpose, behaviour, principles and priorities of human life, in the mind first. Values, which are affective concepts that contribute to the education of individuals with superior moral values, have important functions in shaping their behaviours by affecting the beliefs, feelings and preferences of individuals (Ulusoy and Dilmaç, 2012; Güven, 2014). Values which are also considered as abstract, generalized behaviour principles are also cultural knowledge (Aydın, 2003). Values that play an active 
role in human happiness (Tarhan, 2011) are learned by imitating, modelling or through language (reading) (Şen, 2008).

\section{Purpose}

Secondary school period, which is defined as the formal operational stage, is the stage in which value and belief system is structured (Demircan, 2006). So in this critical stage in which values are structured, examining the current qualifications of Turkish textbooks would provide significant benefits for the development of textbooks. In this context, this study aims to determine values taught in the 5th, 6th, 7th and 8th grade Turkish language textbooks and to analyse the distribution of these values according to themes and grade levels.

\section{Methodology}

This study, which aimed to examine value transfer in the secondary school textbooks in Turkish course, was carried out by qualitative research method. In this study, document review design was used. Document review is the collection and analysis of written, visual and digital materials containing information about the cases and events that are aimed to be investigated (Sönmez \& Alacapınar, 2011, Yıldırım and Şimşek, 2011).

In order to determine the sample of the study, convenience sampling was used from purposeful sampling methods. The sample of the research determined by this method consisted of all the reading texts and poems in the 5th, 6th, 7th and 8th grade Turkish textbooks used in the academic year of 2017-2018. In addition, the listening/watching and reading texts in the textbooks were included in the sample of the study.

In the study, Value Analysis Form prepared by Cengiz and Duran (2017) was used to analyse the data obtained from secondary school Turkish textbooks. The data obtained in this study were analysed by descriptive analysis through this form. In this context, forms were prepared for the 5th, 6th, 7th and 8th grades and were classified according to the themes and the titles of the texts in each book. Then, the listening/ watching and reading texts and poems in these books were examined respectively and marked on value Analysis Form. After all the textbooks were examined in this way, the data obtained from value Analysis Forms were analysed within the plan created under the themes in the textbooks and are summarized then classified according to the grade level. The frequency 
values related to the findings obtained after this classification were tabularized according to the grade levels.

\section{Findings}

As a result of the research, values of aesthetics ( $\mathrm{f}=253)$, kindness ( $\mathrm{f}=126)$, happiness ( $f=112$ ), love ( $f=104)$ were the most given and values of peace $(f=4)$, hospital ity $(\mathrm{f}=7)$ and tolerance $(\mathrm{f}=13)$ were the least given at 5 th grade level. At 6 th grade level, values of love $(f=197)$, aesthetics ( $f=136)$, kindness ( $\mathrm{f}=133$ ) and diligence $(\mathrm{f}=129)$ were the most given, while values of hospitality and simplicity were not given at all; however, it was determined that values of cleannes s $(\mathrm{f}=5)$, tolerance $(\mathrm{f}=5)$ and peace $(\mathrm{f}=9)$ were the least given. At the 7th grade level, values of aesthetics ( $\mathrm{f}=453)$, sincerity $(\mathrm{f}=152)$ and patriotism $(\mathrm{f}=133)$ were the most given and values of simplicity $(\mathrm{f}=1)$, hospitality $(\mathrm{f}=3)$, freedom ( $\mathrm{f}=4$ ) and peace $(\mathrm{f}=6)$ were the least given. At the 8th grade level, values of aesthetics $(\mathrm{f}=231)$, love $(\mathrm{f}=205)$, diligence $(\mathrm{f}=143)$ and respect $(\mathrm{f}=113)$ were the most given and values of peace $(\mathrm{f}=1)$, simplicity $(\mathrm{f}=4)$, modesty $(\mathrm{f}=6)$ were the least given. When looking at values given at 5 th, 6 th, 7 th and 8 th grade levels as a whole, it is seen that values of aesthetics ( $\mathrm{f}=1073)$, love ( $\mathrm{f}=602)$, kindness ( $\mathrm{f}=428$ ), diligence $(\mathrm{f}=395)$, patriotism $(\mathrm{f}=387)$ and happiness $(\mathrm{f}=401)$ were the most given and values of peace $(\mathrm{f}=20)$, simplicity $(\mathrm{f}=23)$, modesty $(f=37)$, tolerance $(f=41)$ and freedom $(f=56)$ were the least given. When the transfer of values by the grade level is examined, it can be said that there is a decrease from 5 th to 6 th grade and this transfer reaches the highest level on the 7th grade and the prevalence of values transferred on the 7th and 8th grades is close to each other.

\section{Conclusion and Discussion}

When the findings obtained from the textbooks within the context of the research are examined as a whole, the most transferred values are found to be aesthetics, love, kindness, diligence, patriotism and happiness, while the least transferred values are peace, simplicity, humility, tolerance and freedom. Similarly, the most transferred value is aesthetic in all of the textbooks analysed by Çırak, Şahin, Özberk and Eriş (2014). When looking at the findings of Çelikpazu and Aktaş (2011) in terms of all textbooks, it was determined that value of aesthetics was not sufficiently covered. When the findings of the textbooks examined in this study are analysed as a whole, the most transferred value is 
aesthetics. This result indicates that the literary texts chosen in the textbooks reflect the aesthetical values and these texts have good qualities in terms of their literary influences. Because a literary text goes beyond the pure knowledge and presents it in an aesthetic dress, which can be regarded as the literary influence of the work (Somuncu, 2010).

Another finding obtained from the research is that the most transferred values in all textbooks after aesthetics are love, kindness, diligence, patriotism and happiness. Findings about values of love and diligence in this study is consistent with the findings of many researches in the literature which examined value transfer in the texts of the Turkish textbooks (Belet and Deveci, 2008; Çrak, Şahin, Özberk and Eriş, 2014; Furat and Mocan, 2014; Mert, 2013; Şentürk and Aktaş, 2015;Yılar, 2016; Yılmaz, Yakar, Arslan, Safranova and Satbay, 2017). In addition, the finding of patriotism is similar to the findings about the transfer of national values (Aral, 2008; Bayram and Elban, 2017; Belet and Deveci, 2008; Şen, 2008; Çelikpazu and Aktaş, 2011; Doğan and Gülüşen, 2011; Firat and Mocan, 2014; Çırak, Şahin, Özberk and Eriş, 2014). On the other hand, it has been found that the transfer of national values was covered less or not covered at all in various studies on value transfer in Turkish textbooks (Firat and Mocan, 2014; Pilav and Erdoğan, 2016). However, in the Turkish Curriculum, it is aimed to transfer values from national to universal. In order to provide a perspective that extends from national to universal in the preparation process of Turkish textbooks, values which are the mirror of ancient Turkish culture should be primarily presented. This will provide positive contributions both for the continuity of our cultural values and for the creation of universal values.

When the results of the research are analysed in terms of value transfer and grade level, it is seen that the texts in 5th grade textbooks have richer content than the 6th grade textbooks in terms of value transfer and although this rich transfer decreases at the 7th grade level, it can be said that value transfer of the texts at the 7th and 8th grade levels is close to each other. Similarly, what Kaygana, Yapic1 and Aytan (2013) claimed in their study is that texts and acquisitions did not fully comply with each other in the text selection in Turkish textbooks and in the association of the selected texts with the themes. As a matter of fact, it was determined that values were not distributed proportionally in various researches (Çelikpazu and Aktaş, 2011; Padem and Aktan, 2014; Pilav and Erdoğan, 2016). In addition, in related literature, many studies revealed that values were not transferred sufficiently in the Turkish textbooks (Çelikpazu and 
Aktaş, 2011; Demir, 2012; Doğan and Gülüşen, 2011; Fırat and Mocan, 2014; Karagöz, 2009; Parlakyıldız, 2009; Pilav and Demir, 2015; Somuncu, 2008; Şen, 2008; Şentürk and Aktaş, 2015).

Şentürk and Aktaş (2015) stated that there are problems in the distribution of values in textbooks (6-8.grades), while Kaşkaya and Duran (2017) found that there are inconsistencies in the distribution of values to the textbooks according to their grade levels (1-4. grades). Doğan and Gülüşen (2011) found that some values were not found in 44 texts of the 111 texts in the textbooks (6th, 7th and 8th grades). Similarly, Pilav and Erdoğan (2016) also found that some values were not included in the texts in the secondary school Turkish textbooks. Similar results were obtained in the study of Mert (2013). One of the current problems in value transfer in Turkish textbooks is that values in the texts are not presented through behavioural examples. In addition, there are not any examples and activities for questioning values that emphasize the affective dimension in order to be internalized (Kaygana, Yapıc1 and Aytan, 2013). To do this, the function of expressing the enthusiasm and excitement in the language should be used in transferring of values instead of a didactic narration and value transfer should be supported by the activities in the texts. Additionally, the text types that will be used for value transfer at each grade level; the activities to be used in the texts, the criteria for the distribution of value transfer in the grade level/theme/text, and the resources and methods to be used in value transfer can be specified separately and value education can be given more systematically. Thus, as time passes value education, within the frame of Turkish education, will bring universal values to a better point while continuing to stick with national values. 


\section{EKLER}

Ek 1: Türkçe dersi 5. sınıf kitabında yer alan değerler

\section{Sınıf Kitabı}

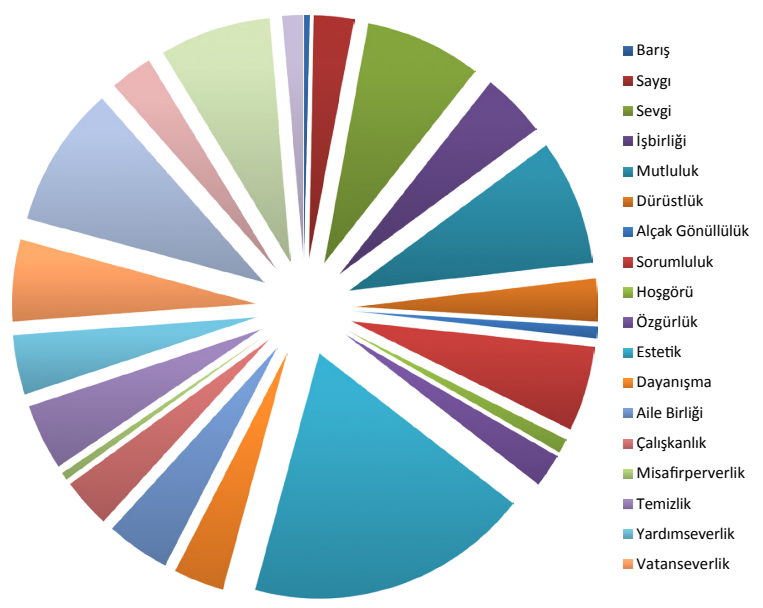

Ek 2: Türkçe dersi 6. sınıf kitabında yer alan değerler

\section{Sınıf Kitabı}

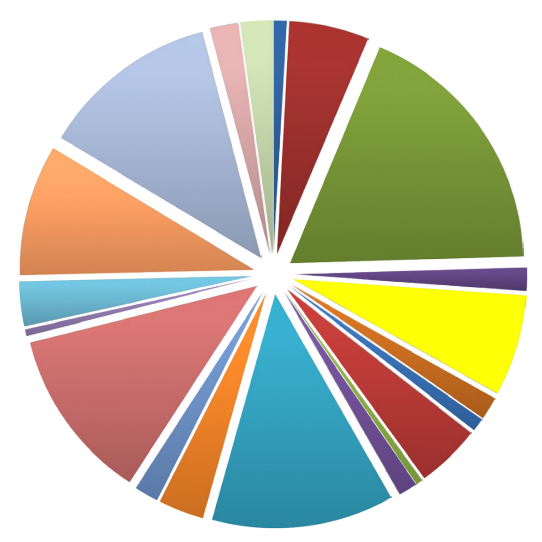

$$
\begin{aligned}
& \text { - Barış } \\
& \begin{array}{l}
\text { - Saygi } \\
\text { a Sevgi }
\end{array} \\
& \text { - İşbirliği } \\
& \text { - Mutluluk } \\
& \text { Dürüstlük } \\
& \text { - Alçak Gönüllülük } \\
& \text { ఐ Sorumluluk } \\
& \text { = Hoşgörü } \\
& \text { —Özgürlük } \\
& \text { Estetik } \\
& \text { ఐDayanışma } \\
& \text { Aile Birliği } \\
& \text { = Çalışkanlık } \\
& \text { - Misafirperverlik } \\
& \text { - Temizlik } \\
& \text { = Yardımseverlik } \\
& \text { = Vatanseverlik } \\
& \text { N Nezaket } \\
& \text { - Arkadaşlık } \\
& =\text { Samimiyet } \\
& \text { in Sadelik }
\end{aligned}
$$


Ek 3: Türkçe dersi 7. sınıf kitabında yer alan değerler

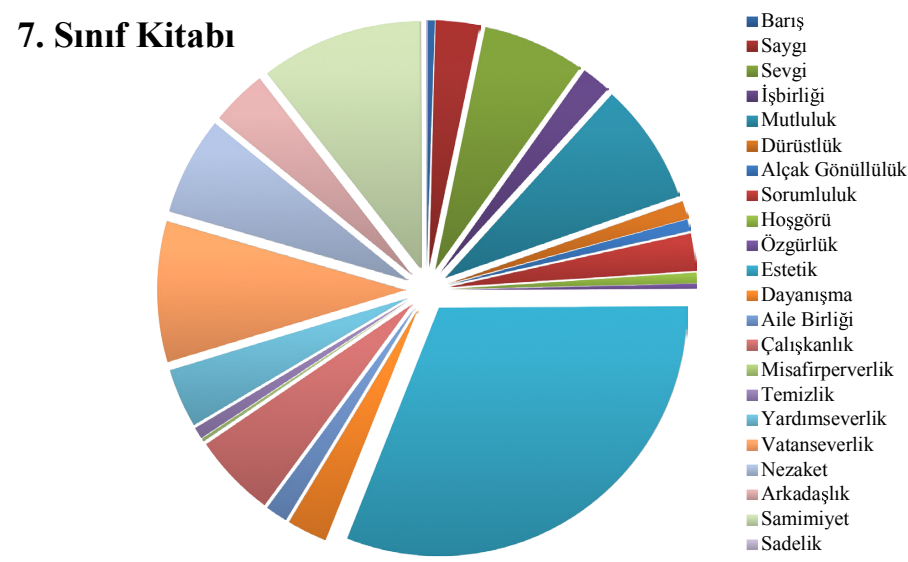

Ek 4: Türkçe dersi 8. sınıf kitabında yer alan değerler

\section{Sinıf Kitabı}

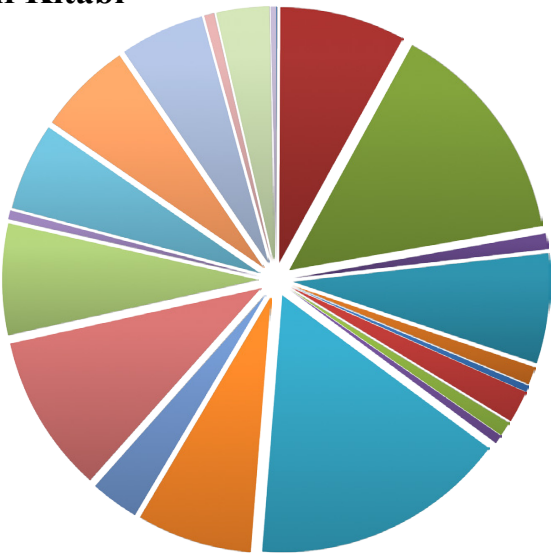

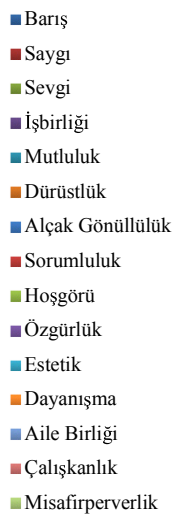

